University of Nebraska - Lincoln

DigitalCommons@University of Nebraska - Lincoln

Finance Department Faculty Publications

Finance Department

7-2009

\title{
Overreaction in the Thrift IPO Aftermarket
}

Geoffrey C. Friesen

University of Nebraska-Lincoln, gfriesen2@unl.edu

Christopher Swift

Nebraska Wesleyan University, cls@nebrwesleyan.edu

Follow this and additional works at: https://digitalcommons.unl.edu/financefacpub

Part of the Finance and Financial Management Commons

Friesen, Geoffrey C. and Swift, Christopher, "Overreaction in the Thrift IPO Aftermarket" (2009). Finance Department Faculty Publications. 5.

https://digitalcommons.unl.edu/financefacpub/5

This Article is brought to you for free and open access by the Finance Department at DigitalCommons@University of Nebraska - Lincoln. It has been accepted for inclusion in Finance Department Faculty Publications by an authorized administrator of DigitalCommons@University of Nebraska - Lincoln. 
Published in Journal of Banking \& Finance 33:7 (July 2009), pp. 1285-1298; doi 10.1016/j.jbankfin.2009.01.002

Copyright $@ 2009$ Elsevier B.V. Used by permission.

Submitted June 30, 2008; accepted January 23, 2009; published online January 31, 2009.

\title{
Overreaction in the Thrift IPO Aftermarket
}

\author{
Geoffrey C. Friesen \\ Department of Finance, University of Nebraska-Lincoln, \\ 237 CBA, Lincoln, NE 68588-0490, United States \\ (Corresponding author - tel 402 472-2334, fax 402 472-5144, email gfriesen2@unl.edu )
}

\section{Christopher Swift}

Department of Business, Accounting, and Economics, Nebraska Wesleyan University, 5000 St. Paul Ave. Lincoln, NE 68504-2794, United States (email cls@nebrwesleyan.edu )

\begin{abstract}
We study the initial returns and long-run performance of a unique sample of thrifts that have recently converted from mutual to stock form. In addition to a full claim on all IPO proceeds, new investors in a converted thrift also receive a claim on all pre-conversion market value at no cost. Thus, the average firm in our sample has a degree of underpricing automatically built into its offer price. We find that after removing the large initial returns, cumulative excess returns for the firms in our sample are positive for 12 months after the IPO. Beginning in the second year after the IPO, the average firm in our sample undergoes a significant price correction that lasts approximately 18 months and which produces negative cumulative abnormal returns for up to 5 years post-issue. Differences in risk-adjusted returns also indicate negative long-run returns, with poor performance concentrated in the second and third years following the IPO. The return differences are most pronounced among the small thrifts in our sample, and are broadly consistent with investor overreaction at the time of the IPO that continues for 6-12 months before prices begin reverting back to fundamental value.
\end{abstract}

Keywords: Overreaction, IPO underpricing, Mutual-to-stock thrift conversion

\section{Introduction}

The IPO market is a natural place to examine aggregate investor behavior following a large, discrete stock price change, since the average IPO has a first day return of between $10 \%$ and $20 \%$ (depending on the time period examined). The cause of the large initial returns is not well understood. Some suggest that the large initial returns result from initial undervaluation, in which case the first-day return simply reflects an adjustment from the offer price to the fundamental value. Others suggest that initial returns reflect investor overreaction to new information on the first day of trading. ${ }^{1}$

Ritter and Welch (2002) document that positive first-day returns are followed by long-run underperformance. One explanation is that negative long-run returns are the result of overreaction to new information on the initial day of trading: Overreaction drives prices above fundamental value, but in the long-run prices converge to fundamental value, and the long-run abnormal returns (excluding the first-day return) are negative. ${ }^{2}$
However, negative long-run returns can be attributed to investor overreaction only if one knows that the IPO was not initially overvalued. Recent work by Purnanandam and Swaminathan (2004) suggests that IPOs are actually overvalued at issue by as much as $50 \%$. In light of this statistic, one cannot attribute negative long-run returns to post-IPO investor overreaction, since the negative returns may simply result from initial overpricing.

We contribute to the study of post-IPO investor overreaction by studying the long-run return properties of a unique set of 221 thrifts that converted from the mutual to stock form of ownership between 1993 and 2000. When thrifts convert from mutual to stock ownership, the original owners (depositors) lose their ownership rights and their entire claim on pre-conversion equity is transferred to the IPO investors at no cost. ${ }^{3}$

Thus, the new shareholders have ownership rights that include all IPO proceeds plus all of the pre-conversion market value of the thrift. In contrast, the new shareholders in a typical IPO have a claim on only a proportion of the pre-conversion market value. If we assume positive pre-conversion market value, then by con-

${ }^{1}$ We do not equate "underpricing" with the initial return, as is commonly done in the literature. We refer to first day returns as such, and use the term "underpricing" only to refer to situations where the IPO price is known to be below the firm's fundamental value (described in more detail below).

${ }^{2}$ Ritter and Welch (2002) suggest it may also reflect a failure to adequately control for firm characteristics.

${ }^{3}$ Prior to conversion, mutual thrift depositors are fixed claimants with apparent ownership rights to residual equity. However, Smith and Underwood (1997) discuss that although the residual profits of a mutual thrift belong collectively to depositors, they are individually unable to exercise their rights as equityholders. In other words, mutual depositors are unable to withdraw the mutual thrift's residual profits. If the thrift converts to a stock organization using the sale-of-stock method, depositors have priority in purchasing shares in proportion to their deposited assets. Depositors who choose not to purchase shares are no longer owners but simply fixed claimants with no ownership rights. 
struction the converting thrift IPO is underpriced. In other words, it is not possible for the valuation to be "correct" since IPO investors always receive assets (IPO proceeds plus pre-conversion market value) worth more than the IPO proceeds. Peter Lynch once remarked that from the perspective of the IPO investor, this was equivalent to buying a house, moving in, and finding the seller had left the sale proceeds in the house for the buyer to keep (Wilcox and Williams, 1998). Many investors understand ex ante that this underpricing exists and is unique to thrift demutualizations, although the exact magnitude is not observable. It is not a feature of standard IPOs, bank IPOs or insurance company demutualizations.

The following example illustrates how the built-in underpricing is unique to mutual-to-stock thrift IPOs. Assume two thrifts that are identical except one is privately held and one is organized as a mutual. Without loss of generality, assume the private firm has 100,000 shares; mutual thrifts do not have ownership shares. Further assume that both firms have $\$ 500,000$ of book value equity prior to their IPO and that both firms will raise capital by selling 400,000 shares to outside investors. The key difference is that the new shareholders of the mutual thrift have a claim on all preconversion equity while the new shareholders of the private thrift have a claim on only a proportion of pre-conversion equity.

The current owner of the private thrift owns all 100,000 shares and will sell 400,000 new shares ( $80 \%$ of the company) for expansion resulting in 500,000 shares after the offering. Investment bankers assist the owner in determining the market valuation of the company and estimate the post-conversion market value to be approximately $\$ 5,000,000$; the IPO is fairly priced by setting the issue price at $\$ 10$ per share. This means the company will collect approximately $\$ 4,000,000$ when the shares are sold (less investment banking fees), and the tangible per share book value of the firm will rise from $\$ 5.00$ prior to the IPO to $\$ 9.00$ after. ${ }^{4}$ Moreover, assuming that the estimated market value of $\$ 5,000,000$ is correct, the post-conversion per share market value equals the initial price of $\$ 10$.

The mutual-to-stock IPO involves selling 400,000 shares at the IPO price of $\$ 10$, with stock proceeds (less fees) of approximately $\$ 4,000,000$. In contrast to the private-to-stock conversion, the original owners (depositors) have no shares in the converted firm and are effectively stripped of their claim on pre-conversion equity. The pro forma tangible book value per share following the IPO is $\$ 11.25$ which represents an immediate increase of $\$ 1.25$ or $12.5 \%$ to new shareholders. A post-conversion market value of $\$ 5,000,000$ results in a share price of $\$ 12.50$, and the IPO is therefore underpriced at issue by approximately $25 \%$. In other words, a mutualto-stock thrift conversion results in a direct transfer of wealth to new shareholders at the expense of the original owners (depositors). In fact, as long as the pre-conversion market value of the firm is positive at the time of conversion, Colantuoni (1998) demonstrates that the IPO will be underpriced and a transfer of wealth will occur regardless of the IPO offer price.

The above example illustrates why we know the average issue is not overpriced and why our sample of firms is uniquely suited to test for investor overreaction. For example, since negative abnormal returns can occur only after price rises above fundamen- tal value, any negative long-run risk-adjusted returns observed in our sample must result from investor overreaction to information at some point after the IPO, assuming the thrift was solvent prior to conversion. In particular, negative long-run returns relative to the first-day closing price indicate investor overreaction on the initial trading day. In contrast, if investors initially underreact to information, all long-returns will be positive when measured relative to the first-day closing price. Overreaction after the initial trading day will produce negative returns only during the later, post-issue sub-periods when prices correct.

We find that our sample of converting thrifts demonstrates large first day excess returns of $17.9 \%$; however, even the large magnitude of this initial return need not imply investor overreaction or initial underpricing. Thus, we examine post-IPO cumulative abnormal returns (which exclude the large initial return) to gauge whether investors overreact on the day of the IPO. We find positive cumulative abnormal returns over the first 12 months following the IPO, but negative cumulative abnormal returns at all horizons longer than that. The results suggest that investors overreact on the initial day and possibly during the subsequent 12 months of trading, which is consistent with the results of Purnanandam and Swaminathan (2004).

If prices eventually converge to fundamental value, any overreaction must be followed by negative sub-period returns during a corrective phase. Therefore, analyzing sub-period returns provides insight into the specific timing of overreaction and subsequent correction. We examine returns over 6 month sub-periods for 5 years post IPO, looking at both market adjusted excess returns and alphas from the various factor models mentioned above. Excess returns are significantly positive for the first 6 months after the IPO, and approximately zero in the subsequent 6-month period. This suggests that overreaction continues for approximately 6 months beyond the initial day of trading. It is worth emphasizing that although investors overreact during the first 6 months of trading, nearly all of the overreaction occurs on the initial day of trading.

However, within 12 months following the IPO, the average thrift begins to experience a price correction or mean-reversion towards fundamental value, as measured by negative excess subperiod returns. This correction lasts for approximately 18 months, after which time the sub-period excess returns are approximately zero. Thus, the thrifts in our sample appear to go through a cycle of overreaction and subsequent correction after the IPO. The initial day of trading, as well as the first 6 months after the IPO, are characterized by investor overreaction. Prices stabilize during the following 6-month period then begin a correction process which lasts about 18 months. We also examine differences in riskadjusted returns. While the statistical significance of these results is somewhat weaker, they also demonstrate that the long-run abnormal returns are negative, and that the poor performance is concentrated in the second and third years following the IPO. In addition, the return differences are most pronounced among the smaller thrifts in the sample.

Our study is among the first to examine the long-run performance of these converted thrifts in detail ${ }^{5}$ and is similar to recent

${ }^{4}$ This represents an immediate increase in pro forma tangible book value of $\$ 4.00$ per share to the existing shareholder and an immediate dilution of $\$ 1.00$ per share to new shareholders. Thus, new shareholders are investing approximately $\$ 1.00$ in the present value of growth opportunities of the thrift. While smaller in magnitude, this is consistent with the results of Chung et al. (2005) who document that a large percentage of the IPO offer price reflects the present value of growth opportunities.

${ }^{5}$ Two exceptions are Ritter (1991) and Houge and Loughran (1999), though neither of those studies analyzes the returns for thrifts separately from other financial institutions. Ritter (1991) documents long-run overperformance over a 3-year holding period for financial institutions (banks and thrifts) that went public during the period 1975-1984. In contrast, Houge and Loughran (1999) found that a sample of banks and thrifts that went public from 1983 to 1991 significantly underperformed over a 5 year holding period. In addition, initial thrift returns have been examined by Pettigrew et al. (1999) and Wilcox and Williams (1998). Maksimovic and Unal (1993) study the relation between IPO pricing, first-day returns, and depositor and insider purchases, and find that greater insider ownership predicted higher initial returns. Esty (1997) and Kroszner and Strahan (1996) examine regulatory incentives to convert to stock form. Unal (1997) looks at the appraisal process and how it relates to initial IPO windfall gains. Masulis (1987) looks at probability a firm will convert as a function of thrift size, recent growth and non-interest income. Cole and Mehran (1998) study the performance of converted thrifts before and after expiration of anti-takeover amendments. 
work by Purnanandam and Swaminathan (2004), who interpret empirical data from standard IPOs in light of various behavioral models. Purnanandam and Swaminathan (2004) examine the premarket, first day and long-run performance of a large set of IPOs. They find that relative to industry peers, the median IPO is overvalued at the offer by about $50 \%$ relative to its industry peers. Moreover, the most overvalued IPOs earn the highest first day returns, and experience the most severe subsequent long-run performance. Relative to IPOs that are initially underpriced, the IPOs most initially overvalued earn first day returns that are 5-7\% higher, but earn $20-40 \%$ lower returns over the next 5 years. Their results suggest that the widely documented long-term IPO underperformance may be attributable to both the initial overvaluation of the offerings, followed by further post-issue price increases that eventually reverse over the long-run. The authors interpret their evidence as being consistent with initial investor overreaction to information (measured by the initial overvaluation of the IPO), followed by additional subsequent overreaction (large positive first-day returns), and long-term mean-reversion (long-term underperformance). This interpretation is consistent with the empirical predictions of Daniel et al. (1998).

While their study addresses several important questions, it raises others. First, it is unclear that overpricing in the pre-market can be interpreted as the type of investor overreaction modeled in Daniel et al. (1998). This is because the pre-issue pricing mechanism differs from the open market pricing mechanism: The initial offer price is set by the issuer and underwriter, and only indirectly represents investor demand. If the issuer miscalculates investor demand, or faces incentives that affect the offer price, the pre-offer pricing mechanism may not accurately represent aggregate investor demand. One advantage of our sample is that the pre-issue pricing mechanism for thrifts is highly transparent. The initial valuation pricing formula is regulated, is common knowledge to investors, and is distinctly independent of investor sentiment. Thus, investor demand manifests only in the aftermarket.

Second, if the average IPO is initially overpriced, then one cannot know whether long-run negative returns are due to investor overreaction or simply result from the initial overpricing. The second advantage of our sample of thrifts is that underpricing is known ex ante to many market participants. Thus, any negative excess returns can be attributed to investor overreaction sometime after the IPO. The empirical tests in the paper are based upon this simple insight.

\section{Thrift conversion process}

\subsection{Regulatory process for thrift conversions}

The thrift industry is comprised of both stock and mutual forms of ownership. Mutual organizations are owned by depositors whereas stock thrifts are owned by shareholders. Until the early 1980s, the thrift industry was dominated by mutual ownership. For example, Esty (1997) reports that in 1979 stock thrifts held only $25 \%$ of thrift industry assets. Chaddad and Cook (2004) note that deregulation and macroeconomic forces, such as increased interest rate volatility during the 1980s, changed the competitive environment in which thrifts operate. Mutual thrifts were most vulnerable to these industry shocks since mutual thrifts rely on retained earnings as their only source of capital.

Prior to 1982, stock ownership for a federally chartered thrift was not an ownership structure option. In response to a large number of failed thrifts, laws were changed authorizing stock ownership and mutual-to-stock conversions. To promote stock ownership, Congress passed the Garn-St Germain Depository Act of 1982, which legalized stock ownership and mutual-to-stock conversions for federally chartered thrifts. These changes were successful in attracting mutual thrifts to convert to stock ownership; Chaddad and Cook (2004) report that stock thrifts currently hold approximately $90 \%$ of industry assets.

The primary regulator of thrift institutions is the Office of Thrift Supervision. The current "sale-of-stock" conversion process was adopted by the predecessor to the Office of Thrift Supervision, the Federal Home Loan Bank Board (FHLBB), in 1974. ${ }^{6}$ This process provides for the sale-of-stock of the converting thrift at a price equal to its pro forma market value as determined by an independent appraisal. The sale-of-stock approach was selected since the FHLBB viewed it as the most viable way of minimizing windfall distributions to accountholders (Smith and Underwood, 1997).

A mutual-to-stock conversion begins with the thrift's board of directors drafting and adopting a plan of conversion. The plan of conversion must include subscription priorities, limits on maximum purchases (generally 5\%), provision for the liquidation account and pro forma market valuation of the institution, and additional limits on stock purchases by officers and directors. Once the board approves the conversion plan, the thrift prepares to file its application for approval (Form AC). Form AC consists of the conversion plan, an independent appraisal establishing market value of the thrift, and the proxy statement. The proxy statement includes the thrift's current financial statements.

The independent appraisal is prepared with respect to regulatory guidelines. An independent appraiser, hired by management, establishes the market value for the converting thrift immediately following conversion by comparing the converting thrift with a sample of similar publicly traded thrifts while considering the thrift's intended use of the proceeds. ${ }^{7}$ A minimum and maximum range for the firm's value is computed and reported as $15 \%$ above and below the estimated value after conversion. Management selects the offer size from within this range (Unal, 1997) and thus has some control over the degree of underpricing. This is consistent with the results of Maksimovic and Unal (1993), who find evidence that issue size and underpricing are directly related, and Cagle and Porter (1997) who state that management may be likely to underprice thrift conversion IPOs. However, the choice of issue size will not introduce overpricing even if management chooses an issue size $15 \%$ above the appraised value, since pre-conversion equity is always transferred to IPO investors at no cost.

Following the submission of a complete application, regulatory authorities review the Form AC and give comments on the adequacy of the appraisal, the legal sufficiency of the plan and disclosures, and the accuracy of the accounting. Once the application for conversion is approved, the thrift immediately distributes its proxy statement to members. After a period of 20-45 days, the thrift can hold its special meeting of account holders. The plan must be approved by a majority of the outstanding votes of members unless state law requires a higher percentage for state chartered institutions. As previously stated, the stock offering follows the sale-of-stock approach. The sale-of-stock approach gives depositors and managers the first opportunity to purchase shares

${ }^{6}$ The current sale-of-stock approach was preceded by the free-distribution-of-stock approach that was in force from 1961 to 1963 (Unal, 1997 ). The free-distribution-of-stock approach required that the converting thrift's pre-conversion equity be distributed on a pro rata basis to existing depositors. As noted by Unal (1997), this approach caused numerous problems and was criticized on the grounds that it would result in a windfall to depositors. The Federal Home Loan Bank Board responded by placing a moratorium on free-distribution-of-stock conversions in 1963 followed by a Congressional statutory moratorium on conversions in April 1973 (Unal, 1997).

7 As noted in Pettigrew et al. (1999), some regulatory authorities have expressed concerns that the appraisal value has frequently been set to low. If true, this will serve to increase the degree of underpricing, and therefore not affect the validity of using abnormal returns to make inferences about post-IPO investor behavior. 
(Unal, 1997). If the conversion offering is not oversubscribed, then subscription rights go to members of the thrift who were not eligible depositors or shares are sold to the public.

The FHLBB adopted amendments in 1979 to limit management purchases, which had averaged $34 \%$ of the total stock sold (Smith and Underwood, 1997). Management purchases were limited to 25$35 \%$ (depending on size of the thrift) in the aggregate and managers were restricted from selling any shares purchased in the initial subscription for a period of 1 year (Wilcox, 2006). ${ }^{8}$ These amendments also limited maximum purchases from any person to $5 \%$ (Smith and Underwood, 1997). The subscription rights are nontransferable and can only be exercised by the recipient. Regulations prohibit anyone directly or indirectly from acquiring ownership of more than ten percent of the conversion stock without board approval.

\subsection{The nature of built-in underpricing}

A key feature that differentiates a thrift conversion from the typical IPO is that at the time of conversion, the depositors are stripped of their claim on pre-conversion equity and the claim is automatically transferred to the new shareholders. Since, the net proceeds of the IPO simply become an asset of the converted thrift, IPO investors have a claim to both pre-conversion market value and all proceeds from the stock sale. In other words, the IPO investors have a claim on total pre-conversion market value at no cost to them. To formalize, suppose an economically solvent mutual thrift applies for conversion to stock ownership. Utilizing the model developed by Maksimovic and Unal (1993, p. 1664), let $V_{0}$ represent the value of pre-conversion equity and let $G V_{0}$ measure the present value of pre-conversion growth opportunities. The pre-conversion market value of the thrift is given by:

$$
V_{P}=V_{0}+G V_{0}
$$

Wilcox and Williams (1998) show that solvency implies that $V_{P}$ is positive. ${ }^{9}$ In addition to the IPO proceeds, denoted $V_{\mathrm{IPO}}$, the class of investors purchasing the newly issued shares also receives $100 \%$ ownership of the pre-conversion market value at no cost. The fundamental value of the thrift after conversion equals

$$
V_{T}=V_{P}+V_{\text {IPO }}-K
$$

where $K$ denotes issuance costs. In an efficient market, the postconversion market value will equal the fundamental value, defined in Equation (1), and the first-day price change will equal the fundamental value minus the issue price $V_{\text {IPO }}$.

Let $P_{\text {day } 1}$ denote the market value at the end of the first day of trading. If investors are rational, first day trading will drive the market price from the issue price, $V_{\mathrm{IPO}}$, to fundamental value $V_{\mathrm{T}}$, so that $P_{\text {day } 1}=V_{\mathrm{T}}$. Underreaction may produce a positive return that results in a first day closing price $P_{\text {day } 1}<V_{\mathrm{T}}$, while overreaction will result in $P_{\text {day } 1}>V_{\mathrm{T}}$. Thus, the presence of a positive first day return by no means indicates investor overreaction, though it may provide an incentive for momentum trading in the new issue.

Equation (1) illustrates the underpricing built into thrift con- versions. Thrift IPO investors pay $V_{\mathrm{IPO}}$ and receive assets worth $V_{\mathrm{T}}=V_{\mathrm{P}}+V_{\mathrm{IPO}}-K$. Thus, in addition to a claim on the IPO proceeds themselves, IPO investors also receive a claim on the full pre-conversion market value. As a result, the initial underpricing is equal to the pre-conversion value of the firm $V_{P}-K$. This term is almost certain to be positive for an economically solvent thrift that converts to stock using the sale-of-stock method (Masulis, 1987; Barth et al., 1994; Unal, 1997). In other words, if the pre-conversion thrift is solvent, underpricing is unavoidable. For this reason, Maksimovic and Unal (1993) note that, unlike the typical IPO, a thrift conversion may experience subsequent price appreciation even without informational asymmetries. Wilcox and Williams (1998) find that size of excess first-day returns is highly predictable using pre-conversion firm value..$^{10}$

The near certainty of excess returns to participants of thrift conversions has not escaped regulatory attention. As discussed in Colantuoni (1998), the Office of Thrift Supervision (1994) guidelines seek to eliminate windfall gains on IPOs by setting the expected post-conversion stock price equal to the IPO price, that is, $V_{\mathrm{T}}=V_{\text {IPO }}$. Of course, this is impossible except under the following restrictive conditions: (a) the pre-conversion market value of the firm is zero; or (b) IPO proceeds are invested in negative NPV projects; or (c) the conversion and issuance fees exceed the pre-conversion market value. ${ }^{11}$ Otherwise, $V_{\mathrm{T}}>V_{\mathrm{IPO}}$, the post-issue market value exceeds the IPO price, $V_{\mathrm{IPO}}$ and the issue is underpriced.

Some behavioral theories predict that in environments with large single-day returns, investors may be prone to overreaction which drives prices above fundamental value.12 Daniel et al. (1998) predict initial investor overreaction, followed by additional subsequent overreaction and then mean-reversion. In our setting, their model predicts large, positive first-day returns, positive abnormal returns for a period after the issue, and negative abnormal returns during the meanreversion period. In addition, initial overreaction will lead to negative long-run returns relative to the first-day closing price.

In contrast, the models of Barberis et al. (1998) and Hong and Stein (1999) predict initial investor underreaction, followed by subsequent overreaction and later reversion to fundamental value. Like the Daniel et al. (1998) model, these theories predict positive first-day returns, positive abnormal returns for a period after the issue, and negative abnormal returns during the mean-reversion period. However, because investors initially underreact to information, all long-run returns will be positive when measured relative to the first-day closing price. Excess negative returns will exist only during the later, post-issue sub-periods. Lastly, if investors never overreact to information, one will observe positive or zero abnormal returns over all post-issue sub-periods. The next section examines post-IPO returns in detail.

\section{Data and methodology}

Figure 1 presents four different scenarios of investor reaction at the IPO and in the aftermarket. The four scenarios depict initial in-

${ }^{8}$ Cole and Mehran (1998) find that after the expiration of this lock-up period, managers of the average firm subsequently increased their ownership percentages.

${ }^{9}$ A distinction must be made between the book value and market value of pre-conversion equity, both of which are relevant in the context of the converting firm. Regulatory decisions, including decisions to close or rehabilitate a thrift, are based upon book values, whereas for shareholders the relevant measure of value is the firm's market value. This distinction ultimately blurs prior to the conversion, since the market value of firm equity is unobservable. Kane and Unal (1990) present a model for market-value/book-value relationships for financial institutions. The pre-conversion market value can be viewed as the sum of the market value of both unbooked equity and booked equity. If book value is assumed to be an unbiased estimate of market value, booked equity is the pre-conversion net worth of the converting thrift, and thus an appropriate estimate of pre-conversion market value.

${ }^{10}$ Both Wilcox and Williams (1998) and Colantuoni (1998), utilizing public information available at the time of conversion, present evidence illustrating the predictive nature of excess first-day returns. The explanatory variable used by Wilcox and Williams (1998) is the ratio of pre-conversion equity (book value) to appraised value while Colantuoni (1998) uses the ratio pre-conversion equity (book value) to total assets. The results reported by both show that pre-conversion equity (book value) is highly significant in explaining initial returns.

${ }^{11}$ See Maksimovic and Unal (1993), Unal (1997), Colantuoni (1998), and Wilcox and Williams (1998) for detailed treatments of this issue.

12 Bali et al. (2008) find that the larger an extreme return, the greater the speed of mean-reversion to fundamental value. 


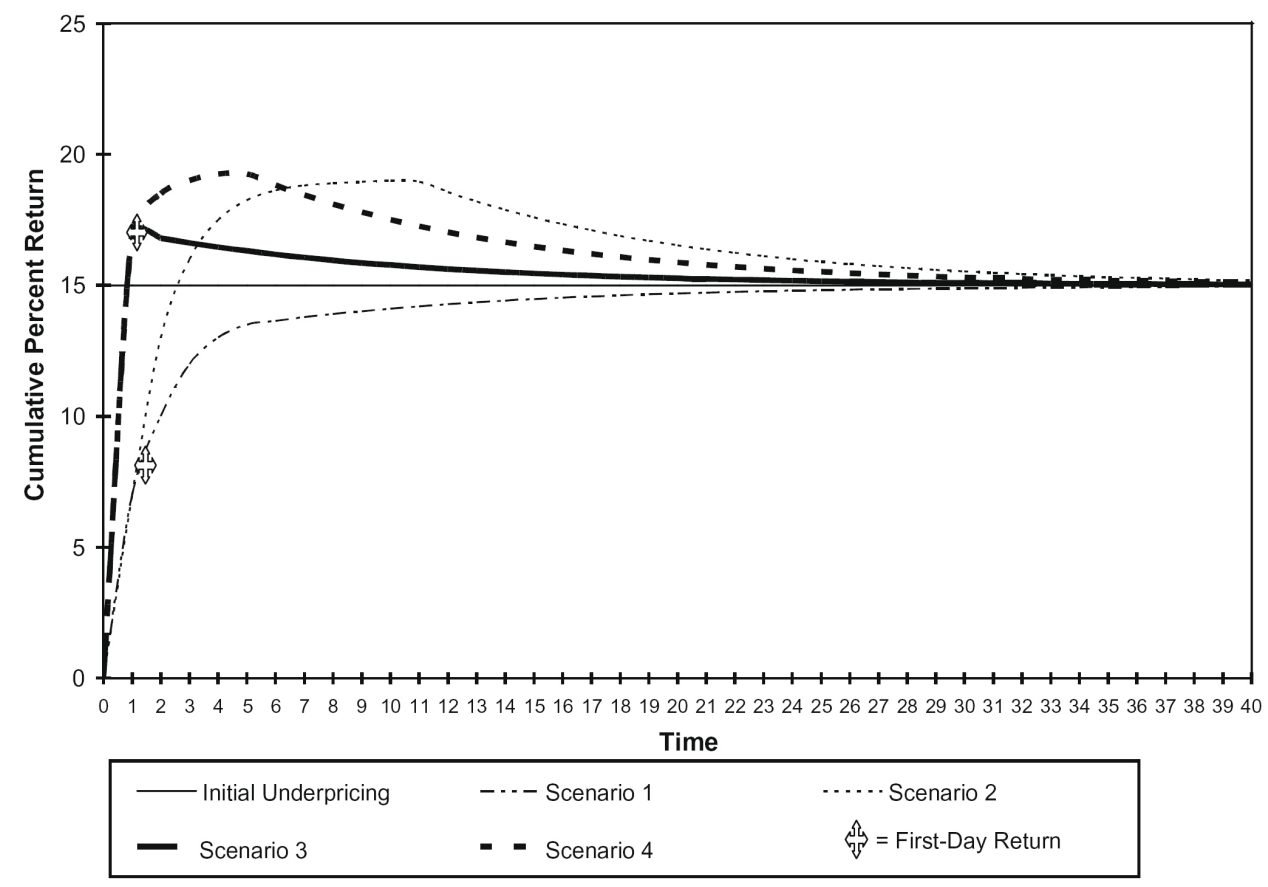

Figure 1. Hypothetical initial investor reaction and subsequent price response to an IPO. The graph presents four different scenarios of initial investor reaction and subsequent price response to an IPO. Without loss of generality, the issue is assumed to be underpriced by $15 \%$, so the horizontal line at $15 \%$ represents the cumulative excess return associated with convergence of the firm value to fundamental value. Scenario 1 displays initial underreaction and subsequent convergence to fundamental value (no overreaction). Scenario 2 presents initial underreaction, followed by subsequent overreaction and eventual convergence to fundamental value. Scenario 2 is consistent with Barberis et al. (1998) and Hong and Stein (1999). Scenario 3 depicts initial overreaction and subsequent mean-reversion to fundamental value. Scenario 4 also displays initial overreaction, followed by subsequent overreaction, and eventual convergence to fundamental value. Scenario 4 is consistent with Daniel et al. (1998).

vestor under- or overreaction to an IPO and eventual reversion of price to fundamental value. Scenario 1 displays initial underreaction followed by slow convergence to fundamental value with no overreaction. Scenario 2 also depicts initial underreaction, followed by subsequent overreaction and eventual convergence to fundamental value. Scenario 2 is consistent with the Barberis et al. (1998) and Hong and Stein (1999) models. Scenario 3 displays initial investor overreaction, followed by subsequent mean-reversion to fundamental value. Scenario 4 displays initial overreaction, followed by additional subsequent overreaction, and eventual convergence to fundamental value. Scenario 4 is consistent with Daniel et al. (1998).

Our first task is to establish that the average thrift in our sample is not overpriced at the issue, which implies that any negative excess returns during the post-IPO period must reflect investor overreaction at some point after the IPO.

\subsection{Sample construction and summary statistics}

We utilize a sample of thrift institutions that converted from mutual to stock ownership during the period between 1993 and 2000. We begin with 1993 since Barth et al. (1994) state that between 1980 and 1990, many thrifts were poorly capitalized following conversion and were eventually seized by regulators. In addition to poor capitalization, the converted thrifts pursued excessive growth strategies or paid excessive dividends or salaries. Thrifts that converted in the 1990s were better capitalized. Our sample ends in 2000, because some of our empirical tests require 5 years of post-IPO return data.

To construct a survivor-bias free sample set of converting thrifts to measure risk-adjusted performance, our sample begins with a listing of 351 firms that filed applications for conversion with the Federal Home Loan Bank Board during 1993-2000.13
From this list, we eliminate all non-publicly traded firms, leaving a sample of 221 firms. The split-adjusted offer price was provided by SNL Securities. Daily returns for the 5 years following conversion are determined using the CRSP NYSE/ AMEX and NASDAQ files. In addition, the Fama and French factors were obtained from Ken French's website.

Table 1 reports summary statistics for the sample of converting firms. Similar to the results in Pettigrew et al. (1999) and Wilcox and Williams (1998), we document an average first-day return of approximately $18 \%$ for the thrifts in our sample. The cumulative return for days 2-5 is not significantly different from zero. Thus, the momentum from the initial day of trading does not appear to carry over into returns on the next 4 days.

Initial underpricing requires a positive pre-conversion market value. We assume that the average thrift has positive pre-conversion market value, but because our sample firms do not trade prior to the IPO, we cannot observe the initial market value $V_{\mathrm{P}}$. However, there are several reasons to believe that this assumption is reasonable. First, both Wilcox and Williams (1998) and Colantuoni (1998) present evidence of a strong correlation between initial excess returns and pre-conversion book value. Moreover, as Unal (1997) notes, it would be difficult to rationalize an investment in an ex ante overpriced firm, since the rational consequence of such overpricing is an immediate loss of investor capital from the negative initial return. ${ }^{14}$ Consistent with average initial underpricing, 214 of our 221 firms have positive initial returns.

We also examine pre-conversion tangible book value. Table 1 reports statistics on IPO proceeds, and pre-conversion tangible book value of equity (pro forma book tangible value minus IPO proceeds). The average IPO raises approximately $\$ 55$ million, with

\footnotetext{
${ }^{13}$ We thank SNL Securities for the list of firms.

${ }^{14}$ Such overpayment might be rational if investors viewed the firm as a gamble, where overpayment is simply the price of admission to the casino.
} 
Table 1. Yearly sample statistics on converting thrifts. Average firm characteristics are reported for each year in the sample. The initial return is defined as the closing price on the first day of trade, minus the offer price, divided by the offer price. Offer prices are provided by SNL Securities and hand verified in the Wall Street Journal. Cumulative return for days two through five is defined as the closing price on the fifth day of trading, minus the closing price on the first day of trading, divided by the closing price on the first day of trading. Number of conversions, IPO Proceeds and pre-conversion equity data are provided by SNL Securities, and the ratio of pre-conversion equity to IPO Proceeds is reported as pre-conversion equity to proceeds ratio. COMPUSTAT data are used to calculate post-conversion assets (data6), post-conversion Price-to-Earnings (P/E) ratio and Price-to-Book (P/B) ratio. P/E price of equity to earnings, and P/B is market value of total assets to book value of total assets. P/E is calculated as mkt_equity/(data53*data54) and P/B is calculated as [(data181 - data35 + prefstk + mkt_equity)/(data6)], where mkt_equity equals (data199*data25), and prefstk equals data10, or data56 if data10 is missing, or data130 if data56 and data10 are missing. Post-conversion market capitalization, average daily trading volume and average bid-ask spread are calculated for each firm using daily CRSP data for all trading days in the calendar year of conversion.

\begin{tabular}{|c|c|c|c|c|c|c|c|c|c|c|c|c|}
\hline Year & $\#$ & $\begin{array}{l}\text { First-day } \\
\text { return (\%) }\end{array}$ & $\begin{array}{l}\text { Cum. return } \\
\text { days 2-5 (\%) }\end{array}$ & $\begin{array}{l}\text { IPO } \\
\text { proceed (000s) }\end{array}$ & $\begin{array}{l}\text { Pre-conversion } \\
\text { equity (000s) }\end{array}$ & $\begin{array}{l}\text { Pre-con equity } \\
\text { to proceeds (\%) }\end{array}$ & $\begin{array}{l}\text { Bid-ask } \\
\text { spread }\end{array}$ & Assets & $\begin{array}{l}\mathrm{P} / \mathrm{E} \\
\text { ratio }\end{array}$ & $\begin{array}{l}\mathrm{P} / \mathrm{B} \\
\text { ratio }\end{array}$ & $\begin{array}{l}\text { Post-conversion } \\
\text { market cap }\end{array}$ & $\begin{array}{l}\text { Avg. daily } \\
\text { volume }\end{array}$ \\
\hline \multicolumn{13}{|c|}{ Panel (a): Sample of converting thrifts } \\
\hline 1993 & 22 & 26.76 & 1.42 & 73,396 & $22,312.3$ & 60.16 & 0.666 & 735,222 & 11.8 & 0.970 & $66,174.8$ & $83,565.5$ \\
\hline 1995 & 51 & 15.45 & 0.51 & 28,338 & $11,364.8$ & 47.51 & 0.470 & 292,201 & 15.6 & 0.981 & $36,345.2$ & $164,885.5$ \\
\hline 1996 & 48 & 12.54 & 0.44 & 34,848 & $12,702.8$ & 39.12 & 0.445 & 629,204 & 22.8 & 1.007 & $43,295.9$ & $46,420.5$ \\
\hline 1997 & 19 & 34.81 & 0.75 & 81,121 & $23,636.6$ & 35.77 & 0.300 & $1,414,610$ & 22.1 & 1.061 & $140,564.4$ & $219,531.0$ \\
\hline Mean & 221 & 17.91 & 0.24 & 54,830 & $20,963.3$ & 45.06 & 0.434 & 648,405 & 18.4 & 0.973 & $72,899.7$ & $112,599.5$ \\
\hline Median & 221 & 17.18 & 0.00 & 23,804 & 9,242 & 40.35 & 0.362 & 308,219 & 15.1 & 0.971 & $29,645.5$ & $25,987.8$ \\
\hline
\end{tabular}

a pre-conversion tangible book value of $\$ 21$ million; the median IPO raises just under $\$ 24$ million, and has a pre-conversion tangible book value of approximately $\$ 9$ million. On average, the ratio of pre-conversion book value to IPO proceeds is $45 \%$ (median value $40 \%$ ). All but one of the 221 firms in our sample had positive tangible book value, again supporting the assumption that the average firm is underpriced at conversion. Thus, while we cannot explicitly measure the firms' pre-IPO market values, these results support the assumption that the average firm in our sample is underpriced. ${ }^{15}$ Even if pre-conversion equity is positive, it is possible that fees associated with the IPO will exceed the value of pre-conversion equity, thus eliminating initial underpricing. This is unlikely to be the case with our sample. Chen and Ritter (2000) document that during the period 1995-1998 over 95\% of IPOs raising between $\$ 20$ and $\$ 80$ million incurred investment banking commissions (fees) of $7 \%$ or less. Since the average pre-conversion equity in our sample is $45 \%$ of the IPO proceeds, the magnitude of IPO fees is too small to drive pre-conversion equity below zero and eliminate initial underpricing. ${ }^{16}$

The remaining results in Table 1 indicate that the average firm has a closing bid-ask spread of $\$ 0.43$, declining from a high of $\$ 0.67$ in 1993 to $\$ 0.27$ in 2000 . Firm assets average \$648 million, the average price-to-earnings $(\mathrm{P} / \mathrm{E})$ ratio is 18.4 , and the average price-to-book $(\mathrm{P} / \mathrm{B})$ ratio is 0.973 . The average thrift has a postconversion market capitalization of $\$ 72.899$ million, and an average daily trading volume of 112,600 shares.

\subsection{Benchmark definition and construction of control groups}

We analyze long-run excess performance on both an absolute and risk-adjusted basis. Absolute excess performance is measured by calculating buy-and-hold abnormal returns (BHARS). Ritter and Welch (2002) argue that when IPOs are measured against like size firms the long-run performance of IPOs is close to zero. We therefore measure BHARS relative to four benchmarks: the CRSP value-weighted index, SNL Thrift Index, and two control groups of size-matched thrifts. The SNL Thrift Index is a non-traded equal weighted index that tracks the total return of the seasoned thrift industry. ${ }^{17}$ The control groups are calculated as follows: For each converting thrift in our sample, we find the firm in the same industry with the closest market value in the year of conversion. To select the sample of matched firms, we first download all thrifts in Compustat for the period 1993-2000. We use four-digit standard industry classification codes (SIC) of the converting thrifts to identify all firms in the thrift industry. From this sample, we eliminate all firms that are part of our sample of converting thrifts. The market values for all remaining firms are computed on December 31 for each sample year, then sorted by year to facilitate matching year of conversion and market value. These firms represent our control group candidates. Due to the regulated environment and the unique financial position of thrifts, we match only on industry and market capitalization. This parallels the practice used in the thrift appraisal process, where size and industry are two key criteria used to identify comparable firms. The control group candidate with the market value closest to the sample firm is selected. Every candidate firm chosen is eliminated to avoid any reuse of control group candidates. In order to exclude initial day returns, the matching firm's IPO date must precede the converting thrift's IPO date. ${ }^{18}$ We construct two control group samples, with the main difference being the length of time the control firms must exist prior to the converting thrift's IPO. The two groups are constructed to balance two offsetting features of the data. On the

${ }^{15}$ Of the 7 firms with negative returns, 5 have returns that are less than $5 \%$ in absolute value, and the firm with the lowest first day return faced subsequent lawsuits alleging that the firm misrepresented its financial condition prior to the IPO. We keep all 221 firms in our sample, but verify that all of our results are qualitatively robust to excluding the seven firms with negative first-day returns. The largest negative return is associated with Carver Bancorp, which converted on October 25, 1994. The stock was offered at $\$ 10$ per share, and closed the first day of trading at $\$ 7.66$ (split adjusted), for a negative $23.44 \%$ return. Carver experienced financial difficulties prior to and after the conversion and the negative first-day return most likely reflects a negative value of equity in place prior to the conversion. However, investors may not have been able to accurately assess the value of pre-conversion equity: Subsequent to its conversion Carver faced litigation alleging that the offering circular contained material omissions and misstatements, and settled a lawsuit in August 1998 related to these misstatements. While this is an isolated and extreme event, we retain it as part of our sample to fully capture the cross-section of post-conversion thrift performance.

${ }^{16}$ We also hand collect data on IPO expenses for the first 15 thrifts (sorted alphabetically) in our sample to measure the magnitude of IPO fees. The average IPO fee as a percentage of total IPO proceeds was 3.53\% with a maximum of $6.61 \%$ and a minimum of $2.35 \%$. IPO expenses for our sample of thrifts appear to be consistent with the results of Chen and Ritter (2000).

${ }^{17}$ We thank SNL Securities for providing daily values for their Thrift Index.

${ }^{18}$ Not all thrift IPOs result from mutual-to-stock conversion. Closely held thrifts and mutual holding companies can also convert to publicly traded thrifts. Neither of these types of IPO are included in our primary sample of converting thrifts, but are included in the list of candidate firms for the control sample. 
one hand, since we are trying to isolate the market dynamics of the converting thrifts shortly after their IPOs, we wish to eliminate all newly-public firms from the control group, so that they are not also experiencing post-IPO dynamics. On the other hand, the thrift industry witnessed considerable consolidation during the sample period. Of our primary sample of 221 firms, only 108 remain at the end of 5 years, with the majority of the disappearing firms acquired by larger banks or thrifts at a sizable acquisition premium. Imposing the requirement that all control thrifts be "well-seasoned" implicitly eliminates many firms from the control group that were themselves acquired at a premium, which reduces the average return for the control group.

In constructing the first control group, we do not impose a waiting period from IPO date to be considered a match firm (we do require that the control firm is publicly traded at the time of the converting thrift's IPO). This construction methodology is similar to the methodology used by SNL Securities to construct the SNL Thrift Index. The second control group imposes the requirement that the matched control firm has been traded publicly for at least 3 years prior to the converting thrift's IPO date, which closely follows Ritter (1991).

Our sample of converting thrifts experienced numerous delistments over the 5 year holding period. Accordingly, it is important that we avoid survivorship bias with respect to our control group. To avoid survivorship bias, we follow Ritter (1991) and select matching firms regardless of when they delist. As a result, our control group experiences delistments during the 5 year holding period similar to our sample of converting thrifts (reported in Table 3 below).

Table 2 reports sample statistics on firm characteristics for the SNL Thrift Index and the two control groups. The average market capitalization for firms in the SNL Index is \$218 million. This is substantially larger than the average size of the converting thrifts, and is driven by the presence of several very large thrifts in the Index, including Washington Mutual, which had a market capitalization of $\$ 29$ billion in 2000. The median market cap for firms in the SNL Index is $\$ 47$ million. The average (median) market capitalization for control groups one and two are much closer to the sample of converting thrifts at \$75 million (\$33 million) and \$135 million (\$41 million), respectively.

Average trading volume in the year of conversion is higher for the converting thrifts than either of the control groups or the SNL Index. Bid-ask spread data is not available for the SNL Index, but the two control groups exhibit the same relative decline in spreads over the sample period, though the absolute level of the spread for the control groups is about twice the spread for the sample of converting thrifts. Converting thrifts have an average (median) priceto-earnings ratio of 18.4 (15.1) compared to 14.1 (12.9) for the SNL Index, 14.1 (12.4) for control group 1 and 13.0 (11.5) for control group 2 . Both the mean and median price-to-book ratio for converting thrifts is 0.97 , compared to an average of 1.55 for the SNL Index and 1.02 for both control groups.

\subsection{Long-run thrift returns}

The most appropriate benchmark is rarely obvious in an event study. However, our entire sample comes from the homogeneous thrift industry, and returns for this industry diverged quite substantially from the value-weighted CRSP index over the sample period (Figure 2). ${ }^{19}$ This suggests that BHARS relative to a broad market index may present a distorted view of true long-run thrift performance. While we calculate and report statistics relative to the market, the analysis and discussion below focuses on measures of excess performance relative to the SNL Thrift index and thrift control groups.

Buy-and-hold abnormal returns (BHARS) are calculated according to

$$
\text { BHARS }=\left[\left(\prod_{t=\text { offerdate }+6}^{\min [\text {,delist }]}\left(1+\gamma_{i t}\right)\right)-\left(\prod_{t=\text { offerdate }+6}^{\min [\text {,delist }]}\left(1+\gamma_{m t}\right)\right)\right] * 100 \text {, }
$$

where $\gamma_{i t}=$ return on the stock $i$ on day $t ; T=$ offer date + number trading days in sample sub-period, or delisting date, if sooner; and $r_{m t}=$ benchmark return day $t$. To exclude positive initial returns, we follow Carter et al. (1998) and exclude the first five trading days from all long-run calculations. Excess long-run performance is measured for up to 5 years following the date of conversion. ${ }^{20} \mathrm{~A}$ converted thrift is included for the lesser of the 5 years following conversion or the delisting date of the thrift.

Table 3 reports cumulative buy-and-hold abnormal returns. To guard against survivorship bias, we first report buy-and-hold excess returns for all sample firms in Panel (a), calculated according to Equation (2). Thus, BHARS for all holding periods are calculated for all 221 firms. If a firm delists prior to the end of the holding period, that firm's BHAR is calculated through the delisting date and is included in all subsequent time periods. Several interesting observations emerge from Panel (a). First, mean and median cumulative abnormal returns are either zero or positive over the first 12 months. Thus, in addition to the large first-day return (excluded from all calculations in Table 3), converting thrifts perform somewhat better than other thrifts in the first year after the IPO.

Second, long-run performance becomes negative in year two and remains negative for up to 5 years, regardless of the thrift benchmark utilized. For example, relative to the SNL Index the average cumulative return through the end of year two is $-13.41 \%$ (median $-17.14 \%$ ). The corresponding average abnormal returns are $-12.28 \%$ and $-9.90 \%$ for control groups 1 and 2, respectively. All of these differences are statistically and economically significant. Cumulative abnormal returns continue to decline through month 30 before stabilizing through the end of the 5-year sample period. We also report median returns in Table 3 . The results indicate the median firm underperformed the average thrift with respect to cumulative long-run performance over the 5-year holding period. This result is not unexpected given the thrift industry is characterized by many small firms that are overcapitalized with relatively low margins (American Banker, 2004).

Our sample of converting thrifts decreases by 113 firms over the 60 month holding period. The majority of these firms disappear because they are acquired. Panel (a) returns include the delist return associated with the acquisition. In Panel (b), we report buy-and-hold abnormal returns only for those firms that survive to the end of each holding period, which eliminates all firms acquired during the sample period. Once again, the converted thrifts underperform all benchmarks over the 5 year holding period. The magnitude of underperformance relative to the SNL index is larger in Panel (b) than reported in Panel (a). This is simply because the average returns on acquired thrifts (including the takeover premium) are larger than the average returns on non-acquired thrifts during our sample period. Panel (c) reports survivorship data for the converting thrifts and both control groups. Consistent with the objectives of using a control group methodol-

\footnotetext{
${ }^{19}$ Regressing returns for the SNL Thrift Index on the value-weighted CRSP index results in a market beta that is not significantly different from zero. The returns for the SNL Thrift Index closely mirror the returns of other thrift indexes. For example, data on the American Banker Thrift Index are available from 1997 through 2005, and over this period the American Banker Thrift Index earned cumulative returns of 303\% vs. 311\% for the SNL Index.

${ }^{20}$ We do not control for differences in analyst coverage, since Bradley et al. (2008) find that neither analysts' research coverage nor all-star analyst coverage affect the long-run performance of IPOs.
} 
Table 2. Yearly Sample Statistics on SNL Thrift Index and Control Thrifts. Average firm characteristics are reported for each year in the sample. Data in Panel (a) are provided by SNL Securities, and report average summary statistics for seasoned thrifts that comprise the SNL Thrift Index. For each calendar year, we report the average value for each statistic, and also report average and median values for the entire sample period. Panels (b) and (c) report summary statistics for the two control groups described in the text. Post-conversion market capitalization, average daily trading volume and average bid-ask spread are calculated for each firm using daily CRSP data for all trading days in each calendar year. Assets, P/E ratio and P/B ratio are calculated as described in Table 1.

\begin{tabular}{|c|c|c|c|c|c|c|c|}
\hline Year & $N$ & Post-conversion market cap & Avg. daily volume & Bid-ask spread & Assets & P/E ratio & P/B ratio \\
\hline \multicolumn{8}{|c|}{ Panel (a): SNL thrift index } \\
\hline 1993 & 504 & $107,490.1$ & $22,047.0$ & $\mathrm{n} / \mathrm{a}$ & $1,113,340$ & 11.4 & 1.16 \\
\hline 1994 & 474 & $105,078.3$ & $29,188.5$ & $\mathrm{n} / \mathrm{a}$ & $1,225,963$ & 12.0 & 1.12 \\
\hline 1995 & 442 & $152,836.8$ & $31,050.3$ & $\mathrm{n} / \mathrm{a}$ & $1,430,204$ & 13.2 & 1.17 \\
\hline 1996 & 421 & $202,813.3$ & $33,275.4$ & $\mathrm{n} / \mathrm{a}$ & $1,640,729$ & 14.3 & 1.32 \\
\hline 1997 & 382 & $311,316.5$ & $42,820.3$ & $\mathrm{n} / \mathrm{a}$ & $1,726,479$ & 16.9 & 2.02 \\
\hline 1998 & 337 & $282,548.0$ & $58,721.1$ & $\mathrm{n} / \mathrm{a}$ & $1,915,591$ & 17.9 & 2.17 \\
\hline 1999 & 309 & $224,669.1$ & $60,683.0$ & $\mathrm{n} / \mathrm{a}$ & $2,173,410$ & 15.5 & 1.85 \\
\hline 2000 & 293 & $357,381.7$ & $57,567.7$ & $\mathrm{n} / \mathrm{a}$ & $2,549,171$ & 11.3 & 1.58 \\
\hline Avg. & 3162 & $218,016.7$ & $39,348.0$ & $\mathrm{n} / \mathrm{a}$ & $1,721,860$ & 14.1 & 1.55 \\
\hline Median & 3162 & $47,110.0$ & $36,191.1$ & $\mathrm{n} / \mathrm{a}$ & 366,648 & 12.9 & 1.35 \\
\hline \multicolumn{8}{|c|}{ Panel (b): Control Group 1} \\
\hline 1993 & 22 & $64,081.4$ & $8,278.9$ & 1.043 & 774,603 & 8.95 & 1.01 \\
\hline 1994 & 46 & $82,383.6$ & $27,269.6$ & 0.859 & $1,173,580$ & 11.50 & 0.99 \\
\hline 1995 & 51 & $38,400.4$ & $7,058.3$ & 1.127 & 429,455 & 12.77 & 1.01 \\
\hline 1996 & 48 & $47,342.3$ & $9,838.0$ & 0.712 & 464,575 & 28.53 & 1.03 \\
\hline 1997 & 19 & $133,215.6$ & $14,049.4$ & 0.836 & 765,773 & 17.18 & 1.08 \\
\hline 1998 & 20 & $161,022.6$ & $35,535.1$ & 0.601 & $1,162,530$ & 13.63 & 1.03 \\
\hline 1999 & 9 & $100,665.8$ & $17,383.0$ & 0.248 & 881,635 & 13.46 & 1.01 \\
\hline 2000 & 6 & $91,772.0$ & $14,086.3$ & 0.212 & 759,772 & 18.50 & 0.99 \\
\hline Avg. & 221 & $75,287.1$ & $15,779.8$ & 0.840 & 748,134 & 14.12 & 1.02 \\
\hline Median & 221 & $33,360.4$ & $3,547.1$ & 0.631 & 331,852 & 12.42 & 1.01 \\
\hline \multicolumn{8}{|c|}{ Panel (c): Control Group 2} \\
\hline 1993 & 22 & $123,082.1$ & $20,097.6$ & 1.112 & $1,493,120$ & 8.78 & 1.01 \\
\hline 1994 & 46 & $42,349.8$ & $16,570.1$ & 0.832 & 691,810 & 8.02 & 1.00 \\
\hline 1995 & 51 & $74,433.1$ & $13,032.3$ & 0.707 & 862,209 & 10.33 & 1.01 \\
\hline 1996 & 48 & $81,537.0$ & $11,434.4$ & 0.987 & 854,255 & 18.70 & 1.03 \\
\hline 1997 & 19 & 154.826 .1 & $10,357.8$ & 0.920 & 766,062 & 22.88 & 1.08 \\
\hline 1998 & 20 & $686,327.6$ & $76,283.4$ & 0.604 & $4,792,020$ & 15.54 & 1.04 \\
\hline 1999 & 9 & $61,664.6$ & $10,108.1$ & 0.486 & 644,392 & 11.56 & 0.99 \\
\hline 2000 & 6 & $34,650.5$ & $18,178.5$ & 0.483 & 921,898 & 12.10 & 0.96 \\
\hline Avg. & 221 & $134,736.7$ & $19,681.9$ & 0.827 & $1,186,630$ & 13.03 & 1.02 \\
\hline Median & 221 & $40,536.2$ & $3,841.2$ & 0.631 & 371,364 & 11.46 & 1.01 \\
\hline
\end{tabular}

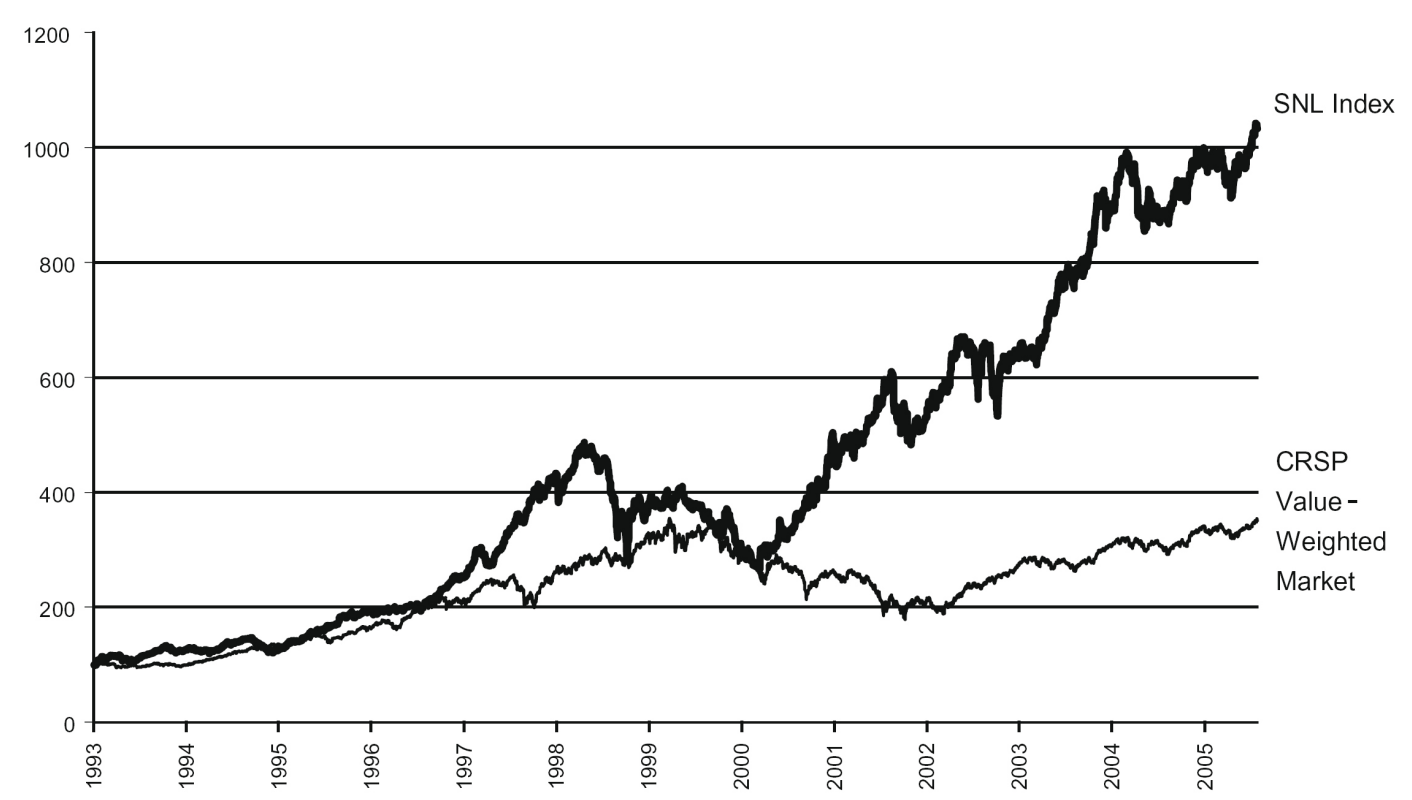

Figure 2. SNL Thrift Index and Value-Weighted Market Index. Figure plots daily closing values for SNL Thrift Index and CRSP value-weighted market index from January 1, 1993 to July 31, 2005, each normalized to a starting value of 100.

ogy, both control groups experience levels of firm attrition similar to the converting thrifts. As a result, the abnormal returns relative to the control groups are qualitatively similar between Panels (a) and (b), particularly for control group one. 
Table 3. Post-IPO long-run returns of converting thrifts. All reported returns exclude the first five trading days after the IPO. Buy-and-hold returns are first calculated for each firm at each horizon, and cross-sectional means or medians are then reported. The left section of the table reports mean buy-and-hold returns for converted thrifts and mean abnormal returns relative to the CRSP value-weighed index. The middle section reports mean and median buy-and-hold abnormal returns relative to the SNL Thrift Index for the sample of converted thrifts and for the two control groups described in the text. The right section reports the mean and median abnormal returns for the sample of converted thrifts relative to each of the control groups. Panel (a) calculates BHARs for every holding period for all 221 firms in the original sample. If a firm disappears prior to the end of a holding period, its return through the date of disappearance is used. Panel (b) calculates BHARs for each holding period conditional upon a firm surviving to the end of the holding period. Panel (c) reports the number of firms surviving to the end of each holding period. $T$-statistics are in parentheses for means and differences in means; for individual medians, parentheses contain $p$-values from a Sign test for difference from zero; for differences in medians, parentheses contain two-sided p-values from a Wilcoxon rank-sum test for differences in medians.

\begin{tabular}{|c|c|c|c|c|c|c|c|c|c|c|c|c|c|}
\hline \multirow[b]{2}{*}{$N$} & \multirow[b]{2}{*}{$\begin{array}{l}\text { Holding } \\
\text { period } \\
\text { thru } \\
\text { month }\end{array}$} & \multirow[b]{2}{*}{$\begin{array}{l}\text { IPO } \\
\text { BHAR } \\
\text { (mean) } \\
(\%)\end{array}$} & \multirow[b]{2}{*}{$\begin{array}{l}\text { IPO } \\
\text { minus } \\
\text { market } \\
\text { (mean) } \\
(\%)\end{array}$} & \multicolumn{6}{|c|}{ BHARS (vs. SNL Index) } & \multicolumn{4}{|c|}{ IPO BHAR minus Control BHAR } \\
\hline & & & & $\begin{array}{l}\text { IPO } \\
\text { minus } \\
\text { SNL } \\
\text { (mean) } \\
(\%)\end{array}$ & $\begin{array}{l}\text { IPO } \\
\text { minus } \\
\text { SNL } \\
\text { (median) } \\
(\%)\end{array}$ & $\begin{array}{l}\text { Control } 1 \\
\text { minus SNL } \\
\text { (mean) } \\
(\%)\end{array}$ & $\begin{array}{l}\text { Control } 1 \\
\text { minus SNL } \\
\text { (median) } \\
(\%)\end{array}$ & $\begin{array}{l}\text { Control } 2 \\
\text { minus SNL } \\
\text { (mean) } \\
(\%)\end{array}$ & $\begin{array}{l}\text { Control } 2 \\
\text { minus SNL } \\
\text { (median) } \\
(\%)\end{array}$ & $\begin{array}{l}\text { IPO minus } \\
\text { Control } 1 \\
\text { (mean) } \\
(\%)\end{array}$ & $\begin{array}{l}\text { IPO minus } \\
\text { Control } 1 \\
\text { (median) } \\
(\%)\end{array}$ & $\begin{array}{l}\text { IPO minus } \\
\text { Control } 2 \\
\text { (mean) } \\
(\%)\end{array}$ & $\begin{array}{l}\text { IPO minus } \\
\text { Control } 2 \\
\text { (median) } \\
(\%)\end{array}$ \\
\hline
\end{tabular}

\section{Panel (a): All sample firms}

\begin{tabular}{|c|c|c|c|c|c|c|c|c|c|c|c|c|c|}
\hline \\
\hline 221 & 6 & 13.31 & $\begin{array}{l}5.28 \\
(4.80)\end{array}$ & $\begin{array}{l}1.15 \\
(1.23)\end{array}$ & $\begin{array}{l}-1.14 \\
(0.224)\end{array}$ & -4.07 & -3.95 & -2.12 & -2.71 & $\begin{array}{l}5.22 \\
(2.67)\end{array}$ & $\begin{array}{l}2.81 \\
(0.003)\end{array}$ & $\begin{array}{l}3.27 \\
(1.93)\end{array}$ & $\begin{array}{l}1.57 \\
(0.107)\end{array}$ \\
\hline 221 & 12 & 29.51 & $\begin{array}{l}10.14 \\
(5.60)\end{array}$ & $\begin{array}{l}1.51 \\
(1.17)\end{array}$ & $\begin{array}{l}-0.58 \\
(0.419)\end{array}$ & -2.45 & -6.49 & -3.53 & -5.62 & $\begin{array}{l}3.96 \\
(1.13)\end{array}$ & $\begin{array}{l}5.91 \\
(0.005)\end{array}$ & $\begin{array}{l}5.04 \\
(1.81)\end{array}$ & $\begin{array}{l}5.04 \\
(0.057)\end{array}$ \\
\hline 221 & 18 & 42.84 & $\begin{array}{l}10.87 \\
(4.38)\end{array}$ & $\begin{array}{l}-5.17 \\
(-2.55)\end{array}$ & $\begin{array}{l}-8.71 \\
(<0.001)\end{array}$ & -0.54 & -4.50 & -4.41 & -8.86 & $\begin{array}{l}-4.63 \\
(-0.97)\end{array}$ & $\begin{array}{l}-4.21 \\
(0.354)\end{array}$ & $\begin{array}{l}-0.76 \\
(-0.21)\end{array}$ & $\begin{array}{l}0.15 \\
(0.768)\end{array}$ \\
\hline 221 & 24 & 52.00 & $\begin{array}{l}6.07 \\
(1.83)\end{array}$ & $\begin{array}{l}-13.41 \\
(-4.97)\end{array}$ & $\begin{array}{l}-17.14 \\
(<0.001)\end{array}$ & -1.14 & -4.78 & -3.51 & -6.68 & $\begin{array}{l}-12.28 \\
(-2.12)\end{array}$ & $\begin{array}{l}-12.36 \\
(0.016)\end{array}$ & $\begin{array}{l}-9.90 \\
(-2.27)\end{array}$ & $\begin{array}{l}-10.46 \\
(0.015)\end{array}$ \\
\hline 221 & 30 & 61.73 & $\begin{array}{l}5.35 \\
(1.28)\end{array}$ & $\begin{array}{l}-17.38 \\
(-5.33)\end{array}$ & $\begin{array}{l}-18.21 \\
(<0.001)\end{array}$ & -1.15 & -10.74 & -2.36 & -5.59 & $\begin{array}{l}-16.23 \\
(-2.43)\end{array}$ & $\begin{array}{l}-7.47 \\
(0.001)\end{array}$ & $\begin{array}{l}-15.02 \\
(-3.00)\end{array}$ & $\begin{array}{l}-12.62 \\
(<0.001)\end{array}$ \\
\hline 221 & 36 & 77.21 & $\begin{array}{l}8.94 \\
(1.75)\end{array}$ & $\begin{array}{l}-16.78 \\
(-4.06)\end{array}$ & $\begin{array}{l}-21.76 \\
(<0.001)\end{array}$ & -3.47 & -10.23 & -1.27 & -4.59 & $\begin{array}{l}-13.31 \\
(-1.85)\end{array}$ & $\begin{array}{l}-11.53 \\
(0.047)\end{array}$ & $\begin{array}{l}-15.51 \\
(-2.60)\end{array}$ & $\begin{array}{l}-17.17 \\
(0.001)\end{array}$ \\
\hline 221 & 42 & 89.46 & $\begin{array}{l}11.19 \\
(1.93)\end{array}$ & $\begin{array}{l}-13.48 \\
(-3.02)\end{array}$ & $\begin{array}{l}-21.53 \\
(<0.001)\end{array}$ & -2.11 & -10.23 & 0.98 & -4.71 & $\begin{array}{l}-11.37 \\
(-1.40)\end{array}$ & $\begin{array}{l}-11.30 \\
(0.082)\end{array}$ & $\begin{array}{l}-14.46 \\
(-2.14)\end{array}$ & $\begin{array}{l}-16.82 \\
(0.005)\end{array}$ \\
\hline 221 & 48 & 96.28 & $\begin{array}{l}9.83 \\
(1.44)\end{array}$ & $\begin{array}{l}-14.09 \\
(-2.79)\end{array}$ & $\begin{array}{l}-22.70 \\
(<0.001)\end{array}$ & -2.21 & -5.87 & -1.35 & -7.00 & $\begin{array}{l}-11.88 \\
(-1.32)\end{array}$ & $\begin{array}{l}-16.83 \\
(0.035)\end{array}$ & $\begin{array}{l}-12.74 \\
(-1.63)\end{array}$ & $\begin{array}{l}-15.70 \\
(0.019)\end{array}$ \\
\hline 221 & 54 & 105.08 & $\begin{array}{l}14.61 \\
(1.84)\end{array}$ & $\begin{array}{l}-13.52 \\
(-2.17)\end{array}$ & $\begin{array}{l}-22.77 \\
(<0.001)\end{array}$ & -5.61 & -6.72 & -0.64 & -2.57 & $\begin{array}{l}-7.91 \\
(-0.81)\end{array}$ & $\begin{array}{l}-16.05 \\
(0.109)\end{array}$ & $\begin{array}{l}-12.88 \\
(-1.42)\end{array}$ & $\begin{array}{l}-20.20 \\
(0.016)\end{array}$ \\
\hline 221 & 60 & 106.38 & $\begin{array}{l}13.70 \\
(1.50)\end{array}$ & $\begin{array}{l}-14.00 \\
(-1.85)\end{array}$ & $\begin{array}{l}-22.77 \\
(<0.001)\end{array}$ & -4.08 & -4.65 & 0.59 & -2.91 & $\begin{array}{l}-9.92 \\
(-0.93)\end{array}$ & $\begin{array}{l}-18.12 \\
(0.038)\end{array}$ & $\begin{array}{l}-14.59 \\
(-1.43)\end{array}$ & $\begin{array}{l}-19.86 \\
(0.006)\end{array}$ \\
\hline \multicolumn{14}{|c|}{ Panel (b): Firms surviving to end of sample period } \\
\hline 221 & 6 & 13.31 & $\begin{array}{l}5.28 \\
(4.80)\end{array}$ & $\begin{array}{l}1.15 \\
(1.23)\end{array}$ & $\begin{array}{l}-1.14 \\
(0.226)\end{array}$ & -4.01 & -3.98 & -2.13 & -2.82 & $\begin{array}{l}5.16 \\
2.62\end{array}$ & $\begin{array}{l}2.84 \\
(0.002)\end{array}$ & $\begin{array}{l}3.28 \\
(1.92)\end{array}$ & $\begin{array}{l}1.68 \\
(0.107)\end{array}$ \\
\hline 221 & 12 & 29.51 & $\begin{array}{l}10.14 \\
(5.60)\end{array}$ & $\begin{array}{l}1.51 \\
(1.17)\end{array}$ & $\begin{array}{l}-0.59 \\
(0.419)\end{array}$ & -2.81 & -7.37 & -3.96 & -6.25 & $\begin{array}{l}4.32 \\
-0.63\end{array}$ & $\begin{array}{l}6.78 \\
(0.005)\end{array}$ & $\begin{array}{l}5.47 \\
(1.95)\end{array}$ & $\begin{array}{l}5.67 \\
(0.024)\end{array}$ \\
\hline 219 & 18 & 42.50 & $\begin{array}{l}10.53 \\
(4.22)\end{array}$ & $\begin{array}{l}-5.79 \\
(-2.91)\end{array}$ & $\begin{array}{l}-8.77 \\
(<0.001)\end{array}$ & -2.60 & -6.40 & -6.72 & -11.57 & $\begin{array}{l}-3.19 \\
(-1.11)\end{array}$ & $\begin{array}{l}-2.37 \\
(0.659)\end{array}$ & $\begin{array}{l}0.93 \\
(0.28)\end{array}$ & $\begin{array}{l}2.80 \\
(0.804)\end{array}$ \\
\hline 207 & 24 & 49.69 & $\begin{array}{l}2.60 \\
(0.76)\end{array}$ & $\begin{array}{l}-17.87 \\
(-7.06)\end{array}$ & $\begin{array}{l}-20.87 \\
(<0.001)\end{array}$ & -7.62 & -10.94 & -8.23 & -12.00 & $\begin{array}{l}-10.25 \\
(-1.78)\end{array}$ & $\begin{array}{l}-9.93 \\
(0.085)\end{array}$ & $\begin{array}{l}-9.64 \\
(-2.28)\end{array}$ & $\begin{array}{l}-8.87 \\
(0.033)\end{array}$ \\
\hline 188 & 30 & 57.31 & $\begin{array}{l}-2.15 \\
(-0.47)\end{array}$ & $\begin{array}{l}-25.48 \\
(-7.93)\end{array}$ & $\begin{array}{l}-25.85 \\
(<0.001)\end{array}$ & -8.22 & -14.96 & -9.96 & -10.23 & $\begin{array}{l}-17.26 \\
(-2.44)\end{array}$ & $\begin{array}{l}-10.89 \\
(0.025)\end{array}$ & $\begin{array}{l}-15.52 \\
(-3.00)\end{array}$ & $\begin{array}{l}-15.62 \\
(0.001)\end{array}$ \\
\hline 172 & 36 & 71.64 & $\begin{array}{l}-5.95 \\
(-1.03)\end{array}$ & $\begin{array}{l}-29.04 \\
(-6.79)\end{array}$ & $\begin{array}{l}-32.05 \\
(<0.001)\end{array}$ & -14.81 & -27.78 & -9.53 & -13.33 & $\begin{array}{l}-14.23 \\
(-2.12)\end{array}$ & $\begin{array}{l}-4.27 \\
(0.131)\end{array}$ & $\begin{array}{l}-19.51 \\
(-2.90)\end{array}$ & $\begin{array}{l}-18.72 \\
(0.001)\end{array}$ \\
\hline 155 & 42 & 81.88 & $\begin{array}{l}-8.38 \\
(-1.21)\end{array}$ & $\begin{array}{l}-28.69 \\
(-5.92)\end{array}$ & $\begin{array}{l}-31.75 \\
(0.001)\end{array}$ & -19.93 & -25.47 & -6.96 & -14.09 & $\begin{array}{l}-8.76 \\
(-1.11)\end{array}$ & $\begin{array}{l}-6.28 \\
(0.278)\end{array}$ & $\begin{array}{l}-21.73 \\
(-2.67)\end{array}$ & $\begin{array}{r}-17.66 \\
(0.001)\end{array}$ \\
\hline 135 & 48 & 87.32 & $\begin{array}{l}-16.80 \\
(-1.92)\end{array}$ & $\begin{array}{l}-33.86 \\
(-5.68)\end{array}$ & $\begin{array}{l}-41.06 \\
(<0.001)\end{array}$ & -22.67 & -22.10 & -14.22 & -24.13 & $\begin{array}{l}-11.19 \\
(-1.00)\end{array}$ & $\begin{array}{l}-18.96 \\
(0.094)\end{array}$ & $\begin{array}{l}-19.64 \\
(-1.82)\end{array}$ & $\begin{array}{l}-16.93 \\
(0.016)\end{array}$ \\
\hline 120 & 54 & 100.41 & $\begin{array}{l}-14.29 \\
(-1.33)\end{array}$ & $\begin{array}{l}-36.54 \\
(-3.97)\end{array}$ & $\begin{array}{l}-58.75 \\
(<0.001)\end{array}$ & -35.98 & -44.14 & -21.35 & -33.56 & $\begin{array}{l}-0.56 \\
(-0.02)\end{array}$ & $\begin{array}{l}15.39 \\
(0.501)\end{array}$ & $\begin{array}{l}-15.19 \\
(-1.07)\end{array}$ & $\begin{array}{l}4.81 \\
(0.022)\end{array}$ \\
\hline 108 & 60 & 101.35 & $\begin{array}{l}-26.81 \\
(-1.61)\end{array}$ & $\begin{array}{l}-47.48 \\
(-3.41)\end{array}$ & $\begin{array}{l}-68.72 \\
(<0.001)\end{array}$ & -36.86 & -43.65 & -19.79 & -27.89 & $\begin{array}{l}-10.62 \\
(-0.27)\end{array}$ & $\begin{array}{l}-25.07 \\
(0.025)\end{array}$ & $\begin{array}{l}-24.74 \\
(-1.39)\end{array}$ & $\begin{array}{l}-38.54 \\
(<0.001)\end{array}$ \\
\hline
\end{tabular}

Panel (c): Number of firms surviving to end of sample period

\begin{tabular}{|c|c|c|c|}
\hline Survive thru month & Firms in thrift sample & Firms in control Group 1 & Firms in control Group 2 \\
\hline 6 & 221 & 218 & 215 \\
\hline 12 & 221 & 213 & 205 \\
\hline 18 & 219 & 190 & 185 \\
\hline 24 & 207 & 170 & 170 \\
\hline 30 & 188 & 154 & 153 \\
\hline 36 & 172 & 138 & 136 \\
\hline 42 & 155 & 123 & 127 \\
\hline 48 & 135 & 116 & 118 \\
\hline 54 & 120 & 107 & 109 \\
\hline 60 & 108 & 99 & 107 \\
\hline
\end{tabular}

The negative long-run returns from Table 3 suggests that investor behavior on the initial day and subsequent 12 months of trading causes prices to rise above fundamental value. To iden- tify specific sub-periods of under and overperformance during the 5-year holding period, we calculate buy-and-hold excess returns for 6-month interim periods after the IPO. The results, presented 
Table 4. Post-IPO sub-period returns for converting thrifts. All reported returns are for individual 6 month post-IPO sub-periods and exclude the first five trading days after the IPO. The left section of the table reports mean buy-and-hold returns for converted thrifts and mean abnormal returns relative to the CRSP value-weighed index for individual 6 month post-IPO sub-periods. The middle section reports mean and median buy-and-hold abnormal returns relative to the SNL Thrift Index for the sample of converted thrifts and for the two control groups described in the text. The right section reports the mean and median abnormal returns for the sample of converted thrifts relative to each of the control groups. Buy-and-hold returns are calculated for each firm that survives to the beginning of the stated sub-period, and cross-sectional means or medians are reported. $T$-statistics are in parentheses for means and differences in means; for individual medians, parentheses contain $p$-values from a Sign test for difference from zero; for differences in medians, parentheses contain two-sided $p$-values from a Wilcoxon rank-sum test for differences in medians.

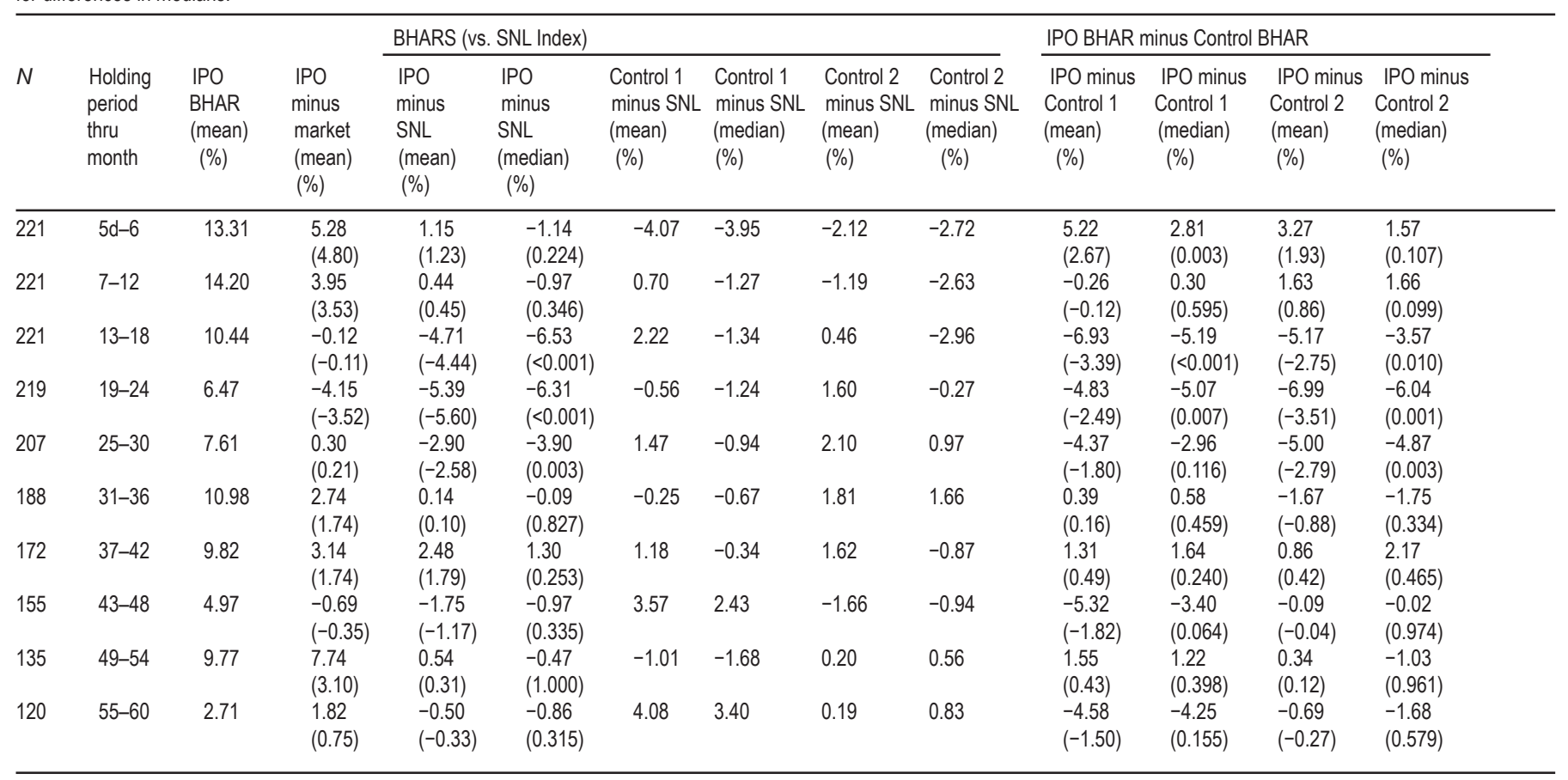

in Table 4, indicate that the sample of converted thrifts continues to earn excess positive returns for the six months after the IPO. These returns are statistically significant relative to the two control groups, but insignificant when measured relative the SNL Index. The excess returns over the $[7,12]$ month sub-period are not significantly different from zero.

The most striking results from Table 4 are the excess returns over the $[13,18],[19,24]$, and $[25,30]$ month sub-periods. The average (median) thrift underperforms the SNL Index by $4.71 \%$ $(6.53 \%), 5.39 \%(6.31 \%)$ and $2.90 \%(3.90 \%)$ in these three periods, respectively. The magnitude of the underperformance is slightly larger relative to either of the control groups. These returns are consistent with correction of earlier investor overreaction. Interestingly, the time-horizon over which this mean-reversion occurs is roughly the same as the mean-reversion horizon associated with the momentum effect first documented by Jegadeesh and Titman (1993).

Taken together, the results in Table 3 and Table 4 indicate overreaction in the first day of trading (evidenced by negative cumulative post-IPO returns in Table 3), with some evidence of overreaction during the immediate post-conversion period (evidenced by the positive sub-period return in the sub-period 5 days, 6 months). This overreaction largely corrects itself over the subsequent 24month period, after which time the abnormal returns on converted thrifts not significantly different from zero.

\section{Controlling for risk of converted thrifts}

\subsection{Risk-adjusted excess returns}

Buy-and-hold cumulative returns are valid performance metrics only when the sample of firms has the same risk as the bench- mark. To control for possible differences in risk between our sample of thrifts and the SNL Index and control groups, we examine alphas from CAPM, 3-factor and 4-factor models. We also consider several additional factors designed to capture the interest rate exposure of the thrift industry. To capture the direct effect of interest rate exposure, we follow Flannery and James (1984) and use the percentage change in yield-relative calculated from yields on 7-year US Treasury securities. ${ }^{21}$ We also use the percentage change in the SNL Thrift Index to capture the indirect effect of interest rate exposure, as well as any other exposures to latent industry-specific factors. In all models, the CRSP value-weighted index is used as a proxy for the market return.

We analyze alphas both for individual thrifts and a portfolio of thrifts. First, we form a portfolio of newly converted thrifts, and calculate the alphas on this portfolio. A thrift remains in the portfolio for 3 years after conversion, or until it no longer exists, whichever is sooner. Each month, the portfolio return is calculated as the value-weighted average of returns on all thrifts in the portfolio. This produces a monthly time-series of returns, which we regress on the specified set of factors.

Table 5 presents the results for factor model regressions on a portfolio of newly converted thrifts. We report the 5-factor model results only for the SNL Index, since the factor loadings on the SNL Index are statistically significant while yield-relative are statistically insignificant in all models. This is consistent with the results of Schuermann and Stiroh (2006, p. 3), who examine numerous factor models and find that "including additional risk factors (relative to the CAPM) typically generates only a modest gain, and when there are substantial gains (in $R^{2}$ ) it is not from adding interest rate factors thought to be relevant to bank returns, but instead from adding the familiar Fama-French factors, HML and SMB."

${ }^{21}$ Flannery and James (1984) fit an AR(3) process to the yield relative time-series and use the resulting residuals as a measure of unanticipated changes in interest rates. They also analyze the actual changes in the yield relative, and report similar results for both measures. 
Table 5. Cumulative long-run alphas for portfolio of converting thrifts. Table reports estimated parameters from a regression of thrift portfolio return on a set of factors. Alpha is reported as a decimal. MKT is the market return minus the risk free rate; SMB and HML are Fama-French size and book-to-market factors, respectively, UMD is a momentum factor, and SNL is the return on the SNL thrift index. The portfolio contains thrifts that convert over the period 1993-2000, and converted thrifts remain in the portfolio for 3 years, or until the firm ceases to exist, whichever occurs first. Each month, the portfolio return is calculated as the value-weighted average of return on all thrifts in the portfolio. Alpha Diff. equals control group alpha minus Thrift IPO alpha. T-statistics are reported in parentheses.

\begin{tabular}{|c|c|c|c|c|}
\hline Parameters & CAPM & 3-Factor & 4-Factor & 5-Factor (SNL) \\
\hline \multicolumn{5}{|c|}{ Panel (a): Thrift IPO regressions } \\
\hline Alpha & $\begin{array}{l}0.013 \\
(4.41)\end{array}$ & $\begin{array}{l}0.009 \\
(3.60)\end{array}$ & $\begin{array}{l}0.009 \\
(3.31)\end{array}$ & $\begin{array}{l}0.008 \\
(3.38)\end{array}$ \\
\hline MKT & $\begin{array}{l}0.282 \\
(4.33)\end{array}$ & $\begin{array}{l}0.528 \\
(7.51)\end{array}$ & $\begin{array}{l}0.527 \\
(7.53)\end{array}$ & $\begin{array}{l}0.207 \\
(2.58)\end{array}$ \\
\hline SMB & & $\begin{array}{l}0.385 \\
(5.44)\end{array}$ & $\begin{array}{l}0.387 \\
(5.47)\end{array}$ & $\begin{array}{l}0.301 \\
(4.76)\end{array}$ \\
\hline HML & & $\begin{array}{l}0.559 \\
(6.30)\end{array}$ & $\begin{array}{l}0.560 \\
(6.30)\end{array}$ & $\begin{array}{l}0.238 \\
(2.54)\end{array}$ \\
\hline UMD & & & $\begin{array}{l}0.038 \\
(0.82)\end{array}$ & $\begin{array}{l}0.034 \\
(0.83)\end{array}$ \\
\hline SNL & & & & $\begin{array}{l}0.323 \\
(6.11)\end{array}$ \\
\hline$R^{2}(\%)$ & 13.71 & 38.12 & 38.48 & 53.66 \\
\hline \multicolumn{5}{|c|}{ Panel (b): Control Group 1 regressions } \\
\hline Alpha & $\begin{array}{l}0.015 \\
(4.57)\end{array}$ & $\begin{array}{l}0.011 \\
(3.78)\end{array}$ & $\begin{array}{l}0.011 \\
(3.77)\end{array}$ & $\begin{array}{l}0.010 \\
(3.75)\end{array}$ \\
\hline MKT & $\begin{array}{l}0.307 \\
(4.37)\end{array}$ & $\begin{array}{l}0.509 \\
(6.65)\end{array}$ & $\begin{array}{l}0.502 \\
(6.40)\end{array}$ & $\begin{array}{l}0.169 \\
(1.83)\end{array}$ \\
\hline SMB & & $\begin{array}{l}0.386 \\
(4.82)\end{array}$ & $\begin{array}{l}0.383 \\
(4.75)\end{array}$ & $\begin{array}{l}0.296 \\
(3.99)\end{array}$ \\
\hline HML & & $\begin{array}{l}0.521 \\
(5.21)\end{array}$ & $\begin{array}{l}0.518 \\
(5.17)\end{array}$ & $\begin{array}{l}0.185 \\
(1.71)\end{array}$ \\
\hline UMD & & & $\begin{array}{l}-0.022 \\
(-0.42)\end{array}$ & $\begin{array}{l}-0.028 \\
(-0.61)\end{array}$ \\
\hline SNL & & & & $\begin{array}{l}0.343 \\
(5.52)\end{array}$ \\
\hline$R^{2}(\%)$ & 13.32 & 31.90 & 32.00 & 45.79 \\
\hline Alpha Diff. & $\begin{array}{l}-0.002 \\
(-0.45)\end{array}$ & $\begin{array}{l}-0.002 \\
(-0.52)\end{array}$ & $\begin{array}{l}-0.002 \\
(-0.50)\end{array}$ & $\begin{array}{l}-0.002 \\
(-0.56)\end{array}$ \\
\hline \multicolumn{5}{|c|}{ Panel (c): Control Group 2 regressions } \\
\hline Alpha & $\begin{array}{l}0.015 \\
(4.51)\end{array}$ & $\begin{array}{l}0.010 \\
(3.56)\end{array}$ & $\begin{array}{l}0.011 \\
(3.63)\end{array}$ & $\begin{array}{l}0.010 \\
(3.67)\end{array}$ \\
\hline MKT & $\begin{array}{l}0.333 \\
(4.63)\end{array}$ & $\begin{array}{l}0.582 \\
(7.64)\end{array}$ & $\begin{array}{l}0.570 \\
(7.30)\end{array}$ & $\begin{array}{l}0.194 \\
(2.19)\end{array}$ \\
\hline SMB & & $\begin{array}{l}0.382 \\
(4.80)\end{array}$ & $\begin{array}{l}0.378 \\
(4.70)\end{array}$ & $\begin{array}{l}0.279 \\
(3.93)\end{array}$ \\
\hline HML & & $\begin{array}{l}0.619 \\
(6.21)\end{array}$ & $\begin{array}{l}0.615 \\
(6.14)\end{array}$ & $\begin{array}{l}0.238 \\
(2.29)\end{array}$ \\
\hline UMD & & & $\begin{array}{l}-0.040 \\
(-0.76)\end{array}$ & $\begin{array}{l}-0.047 \\
(-1.05)\end{array}$ \\
\hline SNL & & & & $\begin{array}{l}0.389 \\
(6.52)\end{array}$ \\
\hline$R^{2}(\%)$ & 14.73 & 36.55 & 36.85 & 53.39 \\
\hline Alpha Diff. & $\begin{array}{l}-0.002 \\
(-0.40)\end{array}$ & $\begin{array}{l}-0.001 \\
(-0.39)\end{array}$ & $\begin{array}{l}-0.002 \\
(-0.49)\end{array}$ & $\begin{array}{l}-0.002 \\
(-0.45)\end{array}$ \\
\hline
\end{tabular}

This lack of explanatory power for interest rate factors contrasts with the earlier results of Flannery and James (1984). One possible explanation for the reduced sensitivity of thrift returns to interest rate changes is that banks and thrifts today are better able to manage interest rate risk exposure through derivative markets that barely existed when Flannery and James (1984) conducted their study.

The first notable result in Panel (a) is that the estimated market factor loadings are less than one in all models. This suggests that the sample of thrifts, as a group, have less systematic risk than the average stock. The loadings on SMB and HML are large, but consistent with the small average size of converted thrifts (the average IPO in our sample raised approximately $\$ 54.8$ million), as well as the high book-to-market values that result from the appraisal process described above. The addition of the Carhart (1997) momentum factor bolsters the 3-factor model to explain cross-sectional variation in momentum-sorted portfolio returns, and is included to ensure that we control for possible exposure to a momentum factor; however, the thrifts do not appear to have any momentum factor exposure. ${ }^{22}$ The SNL index factor is positive (0.323) and highly significant. The fifth-factor loading indicates that the newly converted thrifts have less systematic risk than their seasoned counterparts. This result is consistent with Esty (1997), who finds that firm risk increases after conversion as managers rationally respond to the incentives embedded in the stock form of ownership. ${ }^{23}$

Also notable are the alphas, which are positive and highly significant for all four models (1.3\% monthly in CAPM, $0.9 \%$ monthly in 3-factor and 4 -factor models, and $0.8 \%$ in 5-factor model). These alphas are consistent with the positive long-run BHARS relative to the market reported in Panel (a) of Table $3 .^{24}$ The alphas are also consistent with the superior thrift industry performance over the sample period. At the same time, their large magnitude suggests a possible omitted variable and thus they should be interpreted cautiously.

Therefore, for comparison purposes we also estimate alphas for both control groups, and report the results in Panels (b) and (c). The estimated factor loadings are nearly identical to the estimated factor loadings for the sample firms, suggesting that the risk characteristics of the control groups closely mirror those of the converting thrifts. Alpha is positive and highly significant for all models (1.5\% monthly in CAPM, 1.1\% monthly in 3-factor and 4factor models and $1.0 \%$ monthly in 5-factor model). We calculate and report the difference in alpha between the sample firms control groups. In all cases, the converting thrift alphas are 10-20 basis points lower than the control group alphas. This suggests that our sample firms underperformed with respect to the control groups, though none of the differences is statistically significant. This may be due to low power, or may indicate that controlling for riskcharacteristics explains the buy-and-hold return differences.

To further analyze the risk-adjusted returns, we estimate our factor models separately for each firm over the 3-year post-IPO period to obtain firm-level parameter estimates. Table 6, Panel (a) reports the cross-sectional averages for the estimated monthly parameters. Once again, alphas are statistically and economically significant, across all models. Panel (b) reports the control group alphas and differences for all models. Again, converting thrift alphas are lower than control group alphas for all models. Six of the eight differences are significant at the $10 \%$ level, and three of the eight are significant at the $5 \%$ level. The qualitative results of Table 5 and Table 6 indicate that even after controlling for risk exposure, the converted thrifts have negative risk-adjusted long-run returns. This finding is consistent with investor overreaction in the initial days of trading following the IPO.

To analyze the risk-adjusted sub-period performance, we rerun daily cross-sectional regressions for converting thrifts and

${ }^{22}$ This does not necessarily imply that the converted thrifts do not experience price momentum. Rather, it simply means that the returns on the thrift portfolio are uncorrelated with the returns on a more broadly-based portfolio of stocks whose selection is based upon extreme recent returns.

${ }^{23}$ Also consistent with this, Iannotta et al. (2007) find that mutual banks have better loan quality and lower asset risk than private or public sector banks in the European banking industry. Because the IPO increases available cash and therefore the overall liquidity of thrift assets, it might appear to be risk-reducing. However, Wagner (2007) finds that increases in bank asset liquidity result in banks taking on new risk that more than offsets the positive effects of the liquidity increase, thereby increasing overall risk.

${ }^{24}$ In panel (b) of Table 3, we reported that long-run BHARS are negative for the subsample of firms that survive to the end of the sample period. Since the regression results in Table 5 include all thrifts, they are directly comparable only to the results in Panel (a) of Table 3. 
Table 6. Cumulative long-run alphas: cross-sectional averages. Table reports crosssectional average parameters from firm-level regressions of monthly thrift return on a set of factors. Alpha is reported as a decimal. MKT is the market return minus the risk free rate; SMB and HML are Fama-French size and book-to-market factors, respectively, UMD is a momentum factor, and SNL is the return on the SNL thrift index, minus the risk free rate. Parameters are estimated separately for each firm over the 3-year post-IPO period. Crosssectional t-statistics for the mean parameters are reported in parentheses. Panel (b) reports cross-sectional average alphas from the same regressions using control group returns.

\begin{tabular}{|c|c|c|c|c|}
\hline Parameters & CAPM & 3-Factor & 4-Factor & 5-Factor \\
\hline \multicolumn{5}{|c|}{ Panel (a): Thrift IPO regressions } \\
\hline Alpha & $\begin{array}{c}0.008 \\
(9.38)\end{array}$ & $\begin{array}{c}0.006 \\
(6.59)\end{array}$ & $\begin{array}{c}0.006 \\
(6.54)\end{array}$ & $\begin{array}{c}0.006 \\
(7.11)\end{array}$ \\
\hline MKT & $\begin{array}{r}0.450 \\
(16.35)\end{array}$ & $\begin{array}{r}0.747 \\
(21.99)\end{array}$ & $\begin{array}{r}0.755 \\
(22.24)\end{array}$ & $\begin{array}{c}0.034 \\
(0.74)\end{array}$ \\
\hline SMB & & $\begin{array}{r}0.409 \\
(16.47)\end{array}$ & $\begin{array}{r}0.417 \\
(18.16)\end{array}$ & $\begin{array}{r}0.210 \\
(6.61)\end{array}$ \\
\hline HML & & $\begin{array}{r}0.805 \\
(19.68)\end{array}$ & $\begin{array}{r}0.799 \\
(18.16)\end{array}$ & $\begin{array}{r}0.158 \\
(3.03)\end{array}$ \\
\hline UMD & & & $\begin{array}{c}-0.019 \\
(-0.58)\end{array}$ & $\begin{array}{c}0.063 \\
(2.10)\end{array}$ \\
\hline SNL & & & & $\begin{array}{r}0.521 \\
(14.47)\end{array}$ \\
\hline Average $R^{2}(\%)$ & 11.42 & 21.64 & 24.11 & 31.38 \\
\hline \multicolumn{5}{|c|}{ Panel (b): Control group alphas } \\
\hline Control 1 Alpha & $\begin{array}{c}0.012 \\
(8.04)\end{array}$ & $\begin{array}{c}0.008 \\
(5.54)\end{array}$ & $\begin{array}{r}0.007 \\
(4.04)\end{array}$ & $\begin{array}{r}0.007 \\
(4.01)\end{array}$ \\
\hline Thrift IPO minus & -0.003 & -0.003 & -0.001 & -0.001 \\
\hline Control 1 & $(-1.99)$ & $(-1.65)$ & $(-0.75)$ & $(-0.71)$ \\
\hline Control 2 Alpha & $\begin{array}{c}0.013 \\
(9.64)\end{array}$ & $\begin{array}{c}0.009 \\
(6.75)\end{array}$ & $\begin{array}{r}0.009 \\
(5.84)\end{array}$ & $\begin{array}{r}0.009 \\
(5.89)\end{array}$ \\
\hline $\begin{array}{l}\text { Thrift IPO minus } \\
\text { Control } 2\end{array}$ & $\begin{array}{l}-0.004 \\
(-2.75)\end{array}$ & $\begin{array}{l}-0.003 \\
(-2.17)\end{array}$ & $\begin{array}{l}-0.003 \\
(-1.72)\end{array}$ & $\begin{array}{l}-0.003 \\
(-1.68)\end{array}$ \\
\hline
\end{tabular}

control groups over each post-IPO sub-period, and report the average daily alphas in Table $7 .{ }^{25}$ We only report the alphas from a 5-factor model (the results from models with fewer factors are qualitatively similar, and slightly stronger). Converting thrifts' average daily alphas range from a low of 2.0 basis points in the [43, 48] month interval to a high of 8.3 basis points in the [7, 12] month interval. Alpha is positive in all sub-periods and highly significant in all but two sub-periods. In addition, we report the difference in alpha between converting thrifts and both control groups for all sub-periods. As with the BHARS analysis, the evidence in Table 7 suggests that the negative abnormal returns are concentrated in the $[13,30]$ month period, though the noise in the data prevents us from making any strong statements about statistical significance.

\subsection{Firm size and interpretation of results}

Banz (1981), Reinganum (1981), and Fama and French (1992) present evidence that firm size influences returns. Thus, we sort our sample of converting thrifts into small and large firms based on inflation adjusted market-capitalizations calculated on December 31 of each firm's IPO year. Table 8 reports cumulative BHARS for the size-based portfolios, while Table 9 reports subperiod BHARS. Since the underperformance in Table 4 was less pronounced relative to the SNL Index than the control groups, we report the size-based results relative to the SNL Index. Results relative to the control groups, omitted for brevity, are qualitatively similar and slightly larger in magnitude.

As shown in Table 8, the underperformance is largely concentrated in the smallest half of firms in our sample. The cumulative long-run abnormal returns for the largest thrifts are not sig-
Table 7. Post-IPO Sub-period daily alphas: cross-sectional averages. Table reports crosssectional average alphas from firm-level regressions of daily thrift return on the following factors: MKT is the market return minus the risk free rate; SMB and HML are Fama-French size and book-to-market factors, respectively; UMD is a momentum factor; and SNL is the return on the SNL thrift index, minus the risk free rate. Alpha is reported as a decimal. Parameters are estimated separately for each firm over the specified post-IPO sub-period. Cross-sectional $t$-statistics for the mean alpha parameters are reported in the last column.

\begin{tabular}{llllrlr}
\hline $\begin{array}{l}\text { Period } \\
\text { (months) }\end{array}$ & $\begin{array}{l}\text { IPO Daily } \\
\text { Alpha } \\
\text { (mean) }\end{array}$ & t-stat & $\begin{array}{l}\text { IPO minus } \\
\text { Control 1 } \\
\text { (mean) }\end{array}$ & $\begin{array}{l}\text { t-stat. } \\
\text { IPO minus }\end{array}$ & $\begin{array}{l}\text { t-stat. } \\
\text { Control 2 } \\
\text { (mean) }\end{array}$ & \\
\hline $7-12$ & 0.00083 & 11.54 & -0.00005 & -0.23 & -0.00006 & -0.39 \\
$13-18$ & 0.00049 & 6.40 & -0.00136 & -1.78 & -0.00007 & -0.23 \\
$19-24$ & 0.00041 & 3.84 & -0.00023 & -1.41 & -0.00098 & -1.14 \\
$25-30$ & 0.00052 & 4.40 & -0.00040 & -1.56 & -0.00019 & -1.23 \\
$31-36$ & 0.00070 & 7.44 & 0.00000 & 0.00 & 0.00025 & 1.64 \\
$37-42$ & 0.00060 & 4.82 & 0.00029 & 0.69 & 0.00024 & 1.55 \\
$43-48$ & 0.00020 & 1.27 & -0.00042 & -1.72 & 0.00017 & 0.62 \\
$49-54$ & 0.00057 & 3.96 & -0.00008 & -0.28 & -0.00008 & -0.37 \\
$55-60$ & 0.00072 & 1.79 & -0.00020 & -0.44 & 0.00030 & 1.45 \\
\hline
\end{tabular}

nificantly different from zero. This finding contrasts with Houge and Loughran (1999) who found large banks performed significantly worse than small banks. One possible explanation is that our sample includes only converted thrifts (which are initially underpriced), while in their sample thrifts are included along with banks and bank holding companies, neither of which have underpricing automatically built-in to the IPO price.

In Table 9, we report buy-and-hold excess returns for 6 month interim periods over the post-IPO sample. The small firms' subperiods returns are negative for all but one period, but statistically significant only over the $[13,18],[19,24]$, and $[25,30]$ (median only) month periods. Interestingly, the sub-period returns for the largest firms are also significantly negative over the same three sub-periods, though these negative returns are largely offset by subsequent positive returns.

Because our sample of converting thrifts consists primarily of smaller firms, the results which utilize daily return data may be biased due to nonsynchronous trading. However, we also examine performance utilizing monthly data. Comparison between the daily and monthly results indicates that the results are largely the same whether daily or monthly returns are used. Since the impact of nonsynchronous trading on monthly returns is minimal (Scholes and Williams, 1977), this suggests that nonsynchronous trading is not a significant factor in our results.

Taken together, our results suggest that investor overreaction drives prices above fundamental value on the initial day of trading, that this overreaction continues for at least 6 months, then corrects between 18 and 30 months after the IPO. These price dynamics are most consistent with the empirical predictions of Daniel et al. (1998), and are also most pronounced for the smallest firms in our sample. Our results are also broadly consistent with the model of Miller (1977) in which heterogeneous beliefs about stock returns leads to overvaluation in the presence of short-sales constraints. ${ }^{26}$ This overvaluation theory predicts that the greater the divergence of opinion, the greater the overvaluation and the lower the realized future returns. It is quite plausible to assume short-sales are difficult or expensive, given the small size and high insider ownership of the thrifts in our sample. While the thrift industry is highly regulated and transparent, if belief differences are strongest among the small thrifts, then our empirical results are also consistent with Miller (1977).

\footnotetext{
${ }^{25}$ Because these sub-periods involve only 6 months, we do not run firm-level regressions with monthly returns.

${ }^{26}$ We thank an anonymous referee for this insight.
} 
Table 8. Cumulative BHARs for portfolios sorted by size. Table reports the average buy-and-hold returns for size-based portfolios of converted thrifts relative to the SNL Thrift Index. Firms are sorted based upon inflation adjusted post-IPO market capitalization. The average abnormal return for each firm is calculated by subtracting the cumulative benchmark return from the firm's cumulative return. The cross-sectional average abnormal returns are reported in the table. $T$-statistics are in parentheses for means; for medians, parentheses contain $p$-values from a Sign test for difference from zero.

\begin{tabular}{|c|c|c|c|c|c|c|}
\hline \multirow[t]{2}{*}{ Thru month } & \multirow[t]{2}{*}{$\mathrm{N}$} & \multicolumn{2}{|l|}{ Small firms } & \multirow[t]{2}{*}{$\mathrm{N}$} & \multicolumn{2}{|l|}{ Large firms } \\
\hline & & IPO minus SNL Index (Mean) (\%) & IPO minus SNL Index (Median) (\%) & & IPO minus SNL Index (Mean) (\%) & IPO minus SNL Index (Median) (\%) \\
\hline 6 & 110 & $\begin{array}{c}-0.67 \\
(-0.47)\end{array}$ & $\begin{array}{l}-4.33 \\
(0.001)\end{array}$ & 111 & $\begin{array}{c}2.97 \\
(2.51)\end{array}$ & $\begin{array}{c}1.86 \\
(0.255)\end{array}$ \\
\hline 12 & 110 & $\begin{array}{c}-0.19 \\
(-0.10)\end{array}$ & $\begin{array}{l}-3.44 \\
(0.152)\end{array}$ & 111 & $\begin{array}{c}3.19 \\
(1.82)\end{array}$ & $\begin{array}{l}0.40 \\
(0.850)\end{array}$ \\
\hline 18 & 110 & $\begin{array}{c}-7.90 \\
(-2.72)\end{array}$ & $\begin{array}{r}-10.30 \\
(0.001)\end{array}$ & 111 & $\begin{array}{c}-2.46 \\
(-0.87)\end{array}$ & $\begin{array}{l}-6.47 \\
(0.008)\end{array}$ \\
\hline 24 & 110 & $\begin{array}{c}-20.63 \\
(-5.67)\end{array}$ & $\begin{array}{l}-23.91 \\
(<0.001)\end{array}$ & 111 & $\begin{array}{l}-6.27 \\
(-1.62)\end{array}$ & $\begin{array}{r}-10.38 \\
(0.008)\end{array}$ \\
\hline 30 & 110 & $\begin{array}{l}-25.20 \\
(-5.67)\end{array}$ & $\begin{array}{l}-24.14 \\
(<0.001)\end{array}$ & 111 & $\begin{array}{c}-9.63 \\
(-2.06)\end{array}$ & $\begin{array}{l}-12.68 \\
(<0.001)\end{array}$ \\
\hline 36 & 110 & $\begin{array}{l}-27.67 \\
(-4.79)\end{array}$ & $\begin{array}{l}-27.01 \\
(<0.001)\end{array}$ & 111 & $\begin{array}{l}-5.98 \\
(-1.04)\end{array}$ & $\begin{array}{r}-18.84 \\
(0.013)\end{array}$ \\
\hline 42 & 110 & $\begin{array}{c}-29.81 \\
(-5.00)\end{array}$ & $\begin{array}{l}-29.69 \\
(<0.001)\end{array}$ & 111 & $\begin{array}{c}2.69 \\
(0.43)\end{array}$ & $\begin{array}{r}-14.25 \\
(0.087)\end{array}$ \\
\hline 48 & 110 & $\begin{array}{l}-31.30 \\
(-4.54)\end{array}$ & $\begin{array}{l}-34.71 \\
(<0.001)\end{array}$ & 111 & $\begin{array}{c}2.96 \\
(0.42)\end{array}$ & $\begin{array}{l}-9.78 \\
(0.129)\end{array}$ \\
\hline 54 & 110 & $\begin{array}{c}-30.34 \\
(-3.14)\end{array}$ & $\begin{array}{l}-39.91 \\
(<0.001)\end{array}$ & 111 & $\begin{array}{c}3.15 \\
(0.41)\end{array}$ & $\begin{array}{l}-6.05 \\
(0.343)\end{array}$ \\
\hline 60 & 110 & $\begin{array}{c}-30.54 \\
(-2.44)\end{array}$ & $\begin{array}{l}-38.68 \\
(<0.001)\end{array}$ & 111 & $\begin{array}{c}2.38 \\
(0.29)\end{array}$ & $\begin{array}{l}-8.25 \\
(0.569)\end{array}$ \\
\hline
\end{tabular}

Table 9. Sub-period BHARs for portfolios sorted by size. Table reports the average buy-and-hold returns over 6 month post-IPO sub-periods for size-based portfolios of converted thrifts relative to the SNL Thrift Index. Firms are sorted based upon inflation adjusted post-IPO market capitalization. Buy-and-hold returns are calculated for each firm that survives to the beginning of the stated sub-period, and cross-sectional averages are reported. The average abnormal return for each firm is calculated by subtracting the benchmark return from the firm's return. The cross-sectional average abnormal returns are reported in the table. T-statistics are in parentheses for means and differences in means; for medians, parentheses contain $p$-values from a Sign test for difference from zero.

\begin{tabular}{|c|c|c|c|c|c|c|}
\hline \multirow[t]{2}{*}{ Sub-period } & \multirow[t]{2}{*}{$\mathrm{N}$} & \multicolumn{2}{|l|}{ Small firms } & \multirow[t]{2}{*}{$\mathrm{N}$} & \multicolumn{2}{|l|}{ Large firms } \\
\hline & & IPO minus SNL Index (Mean) (\%) & IPO minus SNL Index (Median) (\%) & & IPO minus SNL Index (Mean) (\%) & IPO minus SNL Index (Median) (\%) \\
\hline $5 d-6$ & 110 & $\begin{array}{c}-0.67 \\
(-0.47)\end{array}$ & $\begin{array}{l}-4.33 \\
(0.001)\end{array}$ & 111 & $\begin{array}{c}2.97 \\
(2.51)\end{array}$ & $\begin{array}{c}1.86 \\
(0.255)\end{array}$ \\
\hline $7-12$ & 110 & $\begin{array}{c}0.75 \\
(0.49)\end{array}$ & $\begin{array}{l}-1.71 \\
(0.634)\end{array}$ & 111 & $\begin{array}{c}0.12 \\
(0.10)\end{array}$ & $\begin{array}{l}-0.86 \\
(0.448)\end{array}$ \\
\hline 13-18 & 110 & $\begin{array}{l}-5.23 \\
(-3.51)\end{array}$ & $\begin{array}{l}-5.48 \\
(<0.001)\end{array}$ & 111 & $\begin{array}{l}-4.20 \\
(-2.77)\end{array}$ & $\begin{array}{l}-7.23 \\
(<0.001)\end{array}$ \\
\hline $19-24$ & 109 & $\begin{array}{l}-8.21 \\
(-6.03)\end{array}$ & $\begin{array}{l}-8.04 \\
(<0.001)\end{array}$ & 110 & $\begin{array}{c}-2.59 \\
(-1.97)\end{array}$ & $\begin{array}{l}-1.69 \\
(0.294)\end{array}$ \\
\hline $25-30$ & 101 & $\begin{array}{l}-1.79 \\
(-1.12)\end{array}$ & $\begin{array}{l}-2.47 \\
(0.046)\end{array}$ & 105 & $\begin{array}{c}-3.97 \\
(-2.48)\end{array}$ & $\begin{array}{l}-5.93 \\
(0.031)\end{array}$ \\
\hline $31-36$ & 90 & $\begin{array}{l}-0.39 \\
(-0.20)\end{array}$ & $\begin{array}{l}-1.96 \\
(0.461)\end{array}$ & 98 & $\begin{array}{c}0.62 \\
(0.33)\end{array}$ & $\begin{array}{l}0.84 \\
(0.762)\end{array}$ \\
\hline $37-42$ & 82 & $\begin{array}{l}-1.84 \\
(-0.92)\end{array}$ & $\begin{array}{l}-1.28 \\
(0.581)\end{array}$ & 90 & $\begin{array}{c}6.40 \\
(3.48)\end{array}$ & $\begin{array}{c}3.03 \\
(0.026)\end{array}$ \\
\hline $43-48$ & 73 & $\begin{array}{l}-3.83 \\
(-1.52)\end{array}$ & $\begin{array}{l}-3.51 \\
(0.160)\end{array}$ & 82 & $\begin{array}{c}0.11 \\
(0.06)\end{array}$ & $\begin{array}{l}-0.10 \\
(1.000)\end{array}$ \\
\hline $49-54$ & 68 & $\begin{array}{l}-0.02 \\
(-0.01)\end{array}$ & $\begin{array}{l}0.18 \\
(0.904)\end{array}$ & 67 & $\begin{array}{c}1.11 \\
(0.47)\end{array}$ & $\begin{array}{l}-0.87 \\
(0.807)\end{array}$ \\
\hline $55-60$ & 60 & $\begin{array}{l}-1.25 \\
(-0.60)\end{array}$ & $\begin{array}{l}-0.95 \\
(0.519)\end{array}$ & 60 & $\begin{array}{c}0.25 \\
(0.11)\end{array}$ & $\begin{array}{l}-0.86 \\
(0.519)\end{array}$ \\
\hline
\end{tabular}

\section{Conclusion}

We study long-run return properties of a unique set of 221 thrifts that converted from mutual to stock form between 1993 and 2000. Our sample of firms is uniquely suited for examining investor behavior because we know that the average firm is initially underpriced. Thus, any long-run negative returns unambiguously result from investor behavior that drives prices above fundamental value at some point after the IPO.

We find that after removing the large first-day returns, converting thrifts have negative long-run cumulative abnormal returns when measured at horizons of 2-5 years. This is consistent with investor behavior on the initial day of trading that drives prices above fundamental value. We also examine abnormal returns over various sub-periods for evidence of investor overreaction at any time after the IPO. We find that the thrift returns are positive for up to 6 months post-IPO and insignificant in the $[7,12]$ month period, which suggests that prices remain above fundamental value for up to a year following the IPO.

Beginning in year two, abnormal returns are significantly negative, indicating a reversion of price to fundamental value. This reversion is concentrated in the $[13,30]$ month period, after which point abnormal returns are not significantly different from zero. This finding is strongest for the smallest firms in the sample, but 
is significant for the large thrifts as well. We also measure risk-adjusted abnormal performance by using a number of factor models. While the statistical significance of these results is somewhat weaker, they also demonstrate that the long-run abnormal returns are negative, and that the poor performance is concentrated in the second and third years following the IPO. The documented price patterns are consistent with the empirical predictions of Daniel et al. (1998), and are most pronounced for the smallest firms in our sample.

\section{References}

American Banker, 2004 - American Banker, February 23, 2004, "True Picture of Thrifts's Health Lies at the Median."

Bali et al., 2008 - T. Bali, Ozgur K. Demirtas and H. Levy, Nonlinear mean-reversion in stock prices, Journal of Banking and Finance 32 (2008), pp. 767-782.

Banz, 1981 - R.W. Banz, The relationship between return and market value of common stocks, Journal of Financial Economics 9 (1981), pp. 3-18.

Barberis et al., 1998 - N. Barberis, A. Shleifer and R. Vishny, A model of investor sentiment, Journal of Financial Economics 49 (1998), pp. 307-343.

Barth et al., 1994 - J. Barth, R.D. Brumbaugh and A. Kleidon, "Windfall" gains in mutual-to-stock conversions of thrift institutions?, Challenge (1994), pp. 43-49 July-August.

Bradley et al., 2008 - D. Bradley, K. Chan, J. Kim and A. Singh, Are there long-run implications of analyst coverage for IPOs?, Journal of Banking and Finance 32 (2008), pp. 1120-1132.

Cagle and Porter, 1997 - J. Cagle and G. Porter, Conversions of mutual savings institutions: Do initial returns from these IPOs provide investors with windfall profits?, Financial Services Review 6 (1997), pp. 141-150.

Carhart, 1997 - M. Carhart, On persistence in mutual fund performance, Journal of Finance 52 (1997), pp. 57-82.

Carter et al., 1998 - R. Carter, F. Dark and A. Singh, Underwriter reputation, initial returns, and the long-run performance of IPO stocks, Journal of Finance 53 (1998), pp. 285-311.

Cole and Mehran, 1998 - R.A. Cole and H. Mehran, The effect of changes in ownership structure on performance: Evidence from the thrift industry, Journal of Financial Economics 50 (1998), pp. 291-317.

Chaddad and Cook, 2004 - F. Chaddad and M. Cook, The economics of organization structure changes: A US perspective on demutualization, Annals of Public and Cooperative Economics 75 (4) (2004), pp. 575-594.

Chen and Ritter, $2000-\mathrm{H}$. Chen and J. Ritter, The seven percent solution, Journal of Finance 55 (3) (2000), pp. 1105-1131.

Chung et al., 2005 - K. Chung, M. Li and L. Yu, Assets in place, growth opportunities, and IPO returns, Financial Management 34 (2005), pp. 65-88.

Colantuoni, 1998 - J. Colantuoni, Mutual-to-stock conversions: Problems with the pricing of initial public offerings, FDIC Banking Review 11 (1998), pp. 1-9.

Daniel et al., 1998 - K. Daniel, D. Hirshleifer and A. Subrahmanyam, A theory of overconfidence, self-attribution, and security market under- and overreactions, Journal of Finance 53 (1998), pp. 1839-1886.

Esty, 1997 - B. Esty, Organizational form and risk taking in the savings and loan industry, Journal of Financial Economics 44 (1997), pp. 25-55.

Fama and French, 1992 - E.F. Fama and K.R. French, The crosssection of expected stock returns, Journal of Finance 47 (1992), pp. 427-465.

Flannery and James, 1984 - M. Flannery and C. James, The effect of interest rate changes on the common stock returns of financial institutions, Journal of Finance 39 (1984), pp. 1141-1153.

Houge and Loughran, 1999 - T. Houge and T. Loughran, Growth fixation and the performance of bank initial public offerings, 19831991, Journal of Banking and Finance 23 (1999), pp. 1277-1301.
Hong and Stein, $1999-$ H. Hong and J. Stein, A unified theory of underreaction, momentum trading and overreaction in asset markets, Journal of Finance 54 (1999), pp. 2143-2184.

Iannotta et al., 2007 - G. Iannotta, G. Nocera and A. Sironi, Ownership structure, risk and performance in the European banking industry, Journal of Banking and Finance 31 (2007), pp. 2127-2149.

Jegadeesh and Titman, 1993 - N. Jegadeesh and S. Titman, Returns to buying winners and selling losers: Implications for stock market efficiency, Journal of Finance 48 (1993), pp. 65-91.

Kane and Unal, 1990 - E. Kane and H. Unal, Modeling structural and temporal variation in the market's valuation of banking firms, Journal of Finance 45 (1990), pp. 113-136.

Kroszner and Strahan, 1996 - R. Kroszner and P. Strahan, Regulatory incentives and the thrift crisis: Dividends, mutual-to-stock conversions, and financial distress, Journal of Finance 51 (1996), pp. 1285-1319.

Maksimovic and Unal, 1993 - V. Maksimovic and H. Unal, Issue size choice and underpricing in thrift mutual-to-stock conversions, Journal of Finance 48 (1993), pp. 1659-1692.

Masulis, 1987 - R. Masulis, Changes in ownership structure: Conversions of mutual savings and loans to stock charter, Journal of Financial Economics 18 (1987), pp. 29-59.

Miller, 1977 - E.M. Miller, Risk, uncertainty and divergence of opinion, Journal of Finance 32 (1977), p. 1151.

Office of Thrift Supervision, 1994 - Office of Thrift Supervision, 1994. Guidelines for appraisal reports for the valuation of savings institutions converting from the mutual to the stock form of organization. Memorandum.

Pettigrew et al., 1999 - G. Pettigrew, D. Page, J. Jahera and J. Barth, Thrift conversions and windfall profits: An empirical examination, Journal of Real Estate Finance and Economics 18 (1999), pp. 323-338.

Purnanandam and Swaminathan, 2004 - A. Purnanandam and B. Swaminathan, Are IPOs really underpriced?, Review Financial Studies 17 (2004), pp. 811-848.

Reinganum, 1981 - M.R. Reinganum, Misspecification of capital asset pricing: Empirical anomalies based on earnings' yields and market values, Journal of Financial Economics 9 (1981), pp. 19-46.

Ritter, 1991 - J. Ritter, The long-run performance of initial public offerings, Journal of Finance 46 (1991), pp. 3-27.

Ritter and Welch, 2002 - J. Ritter and I. Welch, A review of IPO activity, pricing, and activities, Journal of Finance 57 (2002), pp. 1795-1828.

Scholes and Williams, 1977 - M. Scholes and J. Williams, Estimating betas from nonsynchronous data, Journal of Financial Economics 5 (1977), pp. 309-327.

Schuermann and Stiroh, 2006 - Schuermann, T., Stiroh, K., 2006. Visible and hidden risk factors for banks. Staff Reports, No. 252, Federal Reserve Bank of New York.

Smith and Underwood, 1997 - Smith, D., Underwood, J., 1997. Mutual savings associations and conversion to stock form. Memorandum: Office of Thrift Supervision, Department of the Treasury, Washington, DC; http://www.ots.treas.gov/docs/4/48801.pdf

Unal, 1997 - H. Unal, Regulatory misconceptions in pricing thrift conversions: A closer look at the appraisal process, Journal of Financial Services Research 11 (3) (1997), pp. 239-254.

Wagner, 2007 - W. Wagner, The liquidity of bank assets and banking stability, Journal of Banking and Finance 31 (2007), pp. 121-139.

Wilcox and Williams, 1998 - Wilcox, J., Williams, Z., 1998. Predicting excess returns with public and insider information: The case of thrift conversions. Working Paper RPF-283, University of California at Berkeley.

Wilcox, 2006 - Wilcox, J., 2006. Credit Union Conversions to Banks: Facts, Incentives, Issues and Reforms. Filene Research Institute; http://www.filene.org 